\title{
Fuel resource utilisation in landscapes of settlement
}

\author{
Ian A. Simpson ${ }^{\mathrm{a}, *}$, Orri Vésteinsson ${ }^{\mathrm{b}}$, W. Paul Adderley ${ }^{\mathrm{a}}$, Thomas H. McGovern ${ }^{\mathrm{c}}$ \\ ${ }^{a}$ Department of Environmental Science, University of Stirling, Stirling FK9 4LA, Scotland, UK \\ ${ }^{\mathrm{b}}$ Institute of Archaeology, Iceland, Bárugötu 3, 101 Reykjavík, Iceland \\ ${ }^{\mathrm{c}}$ Department of Anthropology, Hunter College, City University of New York, 695 Park Avenue, New York, NY 10021, USA
}

Received 27 August 2002; received in revised form 11 February 2003; accepted 14 February 2003

\begin{abstract}
One little understood aspect of the settlement and colonisation of Iceland is fuel resource use. In this paper we identify fuel ash residues from temporally constrained middens at two contrasting settlement age sites in Mývatnssveit, northern Iceland, one high status, the other low status and ultimately abandoned. Fuel residues derived from experimental combustion of historically defined fuel resources are used to provide control for thin section micromorphology and complementary image analyses of fuel residue materials found in the midden deposits. The results suggest that fuel resources utilised at the time of settlement were for both low temperature and high temperature use, and included a mix of birch and willow wood, peat, mineral-based turf and cow dung. There are, however, marked variations in the mix of fuel resources utilised at the two sites. This is considered to reflect social regulation of fuel resources and socially driven changes to local and regional environments that may have contributed to the success or failure of early settlement sites in Iceland.
\end{abstract}

(C) 2003 Elsevier Ltd. All rights reserved.

Keywords: Traditional fuel use; Settlement landscapes; Thin section micromorphology; Image analyses; Historical ecology; Iceland; North Atlantic region

\section{Introduction}

Studies of settlement and colonisation are of critical significance in the emerging historical ecology research arena $[3,11,20]$. They can provide a basis from which to understand the role of human decisions in setting new directions of environmental change, indicate the way in which environmental resources were used to create and maintain social structures, and provide an historical foundation for contemporary environmental issues. For these reasons, there is an increasingly active research interest in the Norse settlement of Iceland (landnám-Old Norse: land take) between c. AD 871 and c. AD 1000 which provides a unique opportunity to examine the emergence of complex socialenvironmental interactions during the colonisation of a pristine landscape.

\footnotetext{
* Corresponding author: Tel.: +44-(0)1786-467850; fax: +44-(0)1786-467843.

E-mail address: i.a.simpson@stirling.ac.uk (I.A. Simpson).
}

Until recently, investigations of landnám in Iceland were based on mediaeval documentary sources, notably the Book of Icelanders (Íslendingabók) and the Book of Settlements (Landnámabók). It is now recognised, however, that these texts were written from the mid-twelfth century and contain a constructed view of the past rather than real historical information [4,15]. With dismissal of documentary sources as reliable evidence for the events of landnám in Iceland, understanding of this important period is now increasingly relying on integrated archaeological and palaeo-environmental investigation [43]. Site excavations suggest a pattern of initial settlement founded at open coastal locations or in broad river valleys based on the availability of wetland fodder resources to maintain cows over the winter period, with a secondary phase located in cleared woodland areas controlled by the first settlers [41,42]. Zoo-archaeological evidence from a number of sites across Iceland indicates that the landnám economy was based on dairy products and animal husbandry while also exploiting local wildlife resources, partially 


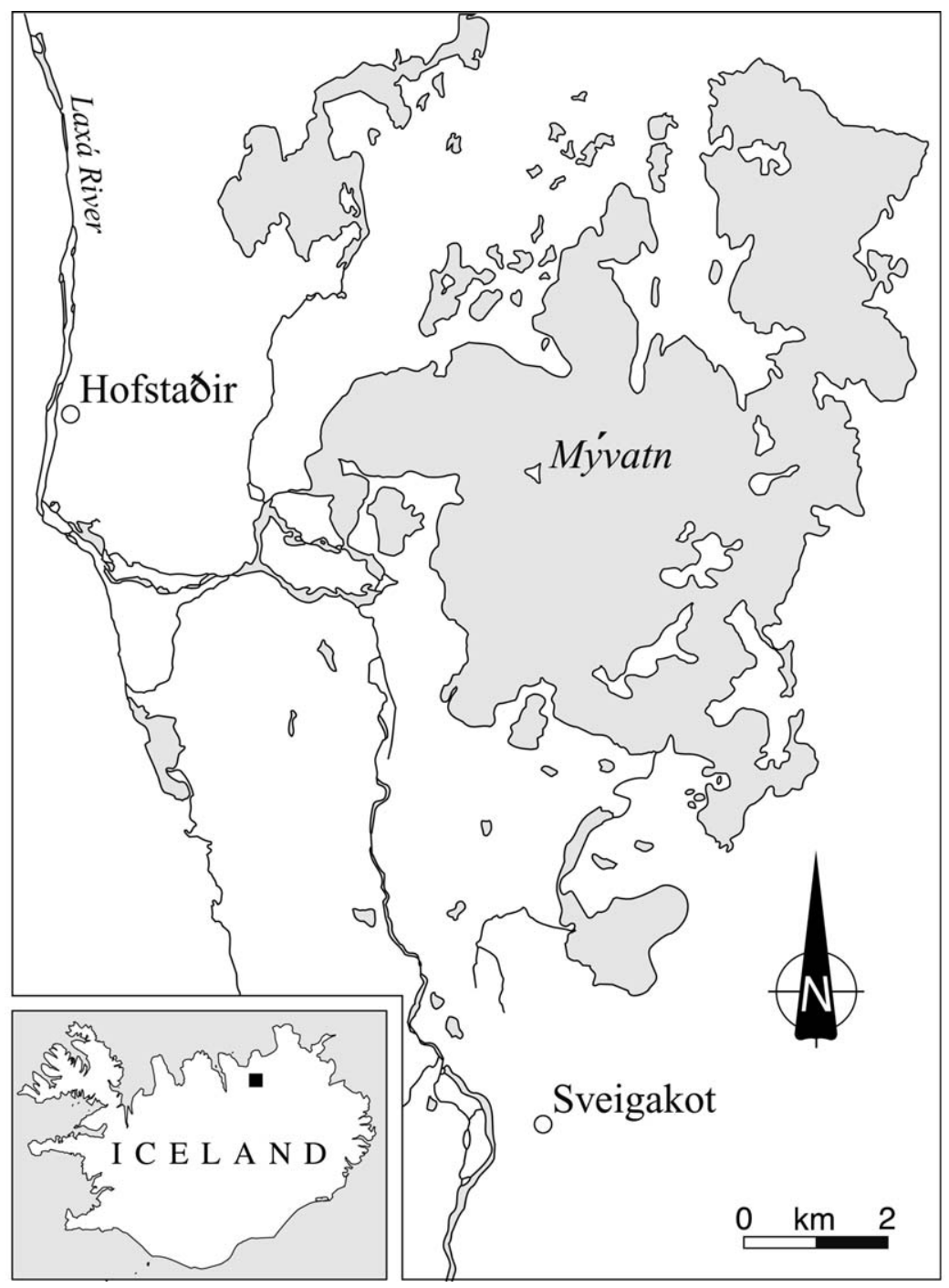

Fig. 1. Location of the Hofstaðir and Sveigakot landnám age sites, Mývatnssveit, northern Iceland.

supporting the view that early settlement location was driven by the need for winter fodder [2]. Associated with landnám activities of landscape clearance for settlement, domestic livestock grazing and fuel utilisation [33] is a dramatic decline in woodland cover seen in the palynological record [18]. This observed decline heralded the onset of historical environmental degradation in Iceland [31] and it is increasingly evident that an understanding of events at landnám is essential to explain later environmental changes [22].

One little understood aspect of landnám is fuel resource use, and so the identification of fuel ash residues associated with two contrasting archaeological sites in Mývatnssveit, northern Iceland, and dated to the settlement period, provides an outstanding opportunity to identify materials used for fuel during this time (Fig. 1). Local fuel resources were a basic necessity of life for early societies, providing light, warmth, the possibility of cooking food and allowing a range of metalworking processes. Fuel ash residues associated with these activities are frequently found in archaeological site stratigraphies, and their analyses offers the opportunity to consider the role of fuel resources in discussions of site function and landscape resource utilisation in changing social and environmental contexts $[26,28]$. Despite the significance of fuel ash residues in archaeological site contexts, the identification of materials used as fuels from fuel ash residues found in site stratigraphies remains a major challenge to geoarchaeologists. Such residues are frequently from multiple sources, are mixed with other forms of occupational debris and have been subjected to a range of post-depositional processes including bioturbation, freeze-thaw and wetting-drying [26]. This frequently precludes the use of analytical methods based on bulk cultural sediment samples to consistently identify fuel ash residues. Alternatively, sediment thin section micromorphology analyses of undisturbed samples supported 
by image analyses techniques has the potential to discriminate between different fuel ash residues in mixed sedimentary environments at the microscopic scale and is the technique applied in this study. Micromorphological indicators of fuel ash residues may include colour, indicative of iron immobilisation when heated [10]; charcoal material $[12,38]$; calcitic pseudomorph crystals [6,7]; and silica phytoliths and diatoms [10]. Such analyses of fuel residues have, in a range of environmental contexts, permitted distinctions to be made between wood sources, including burning temperature, and between grass, sedge and animal manure sources, suggesting that identification of fuel sources in an Icelandic landnám context may be possible.

The first objective of this study is to establish whether experimentally combusted historically defined Icelandic fuel materials have distinctive residue attributes and features that can be observed and quantified in thin section. This provides a controlled basis for a second objective, the identification of fuel residues in the temporally constrained midden stratigraphies of the Hofstaðir and Sveigakot archaeological sites in Mývatnssveit, northern Iceland. In doing so, such analyses can make a critical contribution to debate on the historical ecology of landnám in Iceland, with its implications for understanding human settlement processes and environmental change. This includes discussion on the selection of materials as fuel resources for different activities, social and environmental regulation of fuel resource utilisation, and the contribution that fuel resource availability may have made to the success or failure of early settlement sites.

\section{Methods}

\subsection{Historically defined fuel resource control materials}

Identification of appropriate materials for experimental combustion was made through analyses of the Land Register of Árni Magnússon and Páll Vídalín [24]. The Land Register was systematically compiled between 1702 and 1714 for each farm property in Iceland by several scribes, and normally lists all resources present including materials used as fuels. In pingeyjarsýslur, the counties covering north-eastern Iceland, and including Mývatnssveit, the Land Register was compiled in 1712. Here the scribe had a consistent approach to asking about fuel, not only noting if there were resources such as wood or shrub, but also if dung or driftwood was used as supplements; in this region only 12 entries out of 347 fail to mention fuel. Categorising these, 141 of the farms had access to woodland fuel resources and in coastal localities where woodland was not found, driftwood was an important fuel resource. Shrub is mentioned in 106 farms and was found in all environments including coastal; in 93 cases there was shrub but no wood. In all, $83 \%$ of the farms in pingeyjarsýslur had access to wood or shrub as a fuel resource. Peat and turf were only cut at two farms and one of them also had shrub, so only one farm relied entirely upon peat. However, 48 farms were said to have cut peat in earlier times. Twenty-seven of these also had recourse to shrubland, and 12 had recourse to woodland, suggesting that the peat had not been cut because no other fuel was available, but from choice. Of the remaining farms, most had taken up domestic livestock dung burning. Dung is mentioned as fuel in 116 farms, but in only 26 cases was it the only fuel source available. The use of dung was widespread throughout the region as a supplementary fuel, but was more commonly used where woodland was scarce.

Review of the Land Register for pingeyjarsýslur suggests fuel resources included, in order of importance: birch, willow, peat, turf and domestic livestock dung as the principal fuels, with driftwood, seaweed, and fish-bones as subsidiary or very localised fuel resources. Accordingly, samples of the historically defined principal fuel resource materials were collected from the Mývatnssveit district. Separate samples of moderately humified peat material, well humified mineral-rich turf material material, sheep dung, cow dung, birch wood (Betula pubescens) and willow wood (Salix lanata) were air dried and then combusted in a muffle furnace at $400{ }^{\circ} \mathrm{C}$ and $800{ }^{\circ} \mathrm{C}$ for $60 \mathrm{~min}$, and the ash residues collected and prepared as thin sections. These combustion temperatures represent two situations; high temperature complete combustion $\left(800{ }^{\circ} \mathrm{C}\right)$ as would be routinely found in 'industrial' metal working activity, and low temperature, incomplete combustion $\left(400{ }^{\circ} \mathrm{C}\right)$ as would be more often associated with 'domestic' hearths.

\subsection{Study sites and chronology}

The Hofstaðir site is located in the upper Laxá valley in Mývatnssveit, north-east Iceland on the Pleistocene Palagonite Formation (Fig. 1). Soils associated with the site are layered, freely drained silts, up to $100 \mathrm{~cm}$ in thickness and are classified as andisols derived from tephra and aeolian materials of various origins [19,34]. The archaeological structures of the site include a halllike building over $45 \mathrm{~m}$ in length and over $10 \mathrm{~m}$ in width (Area A; Fig. 2), and an oval shaped pit rimmed by a low earth wall measuring $6.70 \mathrm{~m}$ by $5.75 \mathrm{~m}$ (Area G; Fig. 2; [21]). Earlier analyses using thin section micromorphology established that cultural sediments up to a metre in thickness filling the pit of Area G contain a significant volume of fuel ash residues, and that they are in-filling an early sunken hut with distinct trampled occupation surfaces [30]. Excavation of these silt loam deposits with a $\mathrm{pH}$ range of $6.2-6.8[23,39]$ has established a number of contexts that are evident in field 


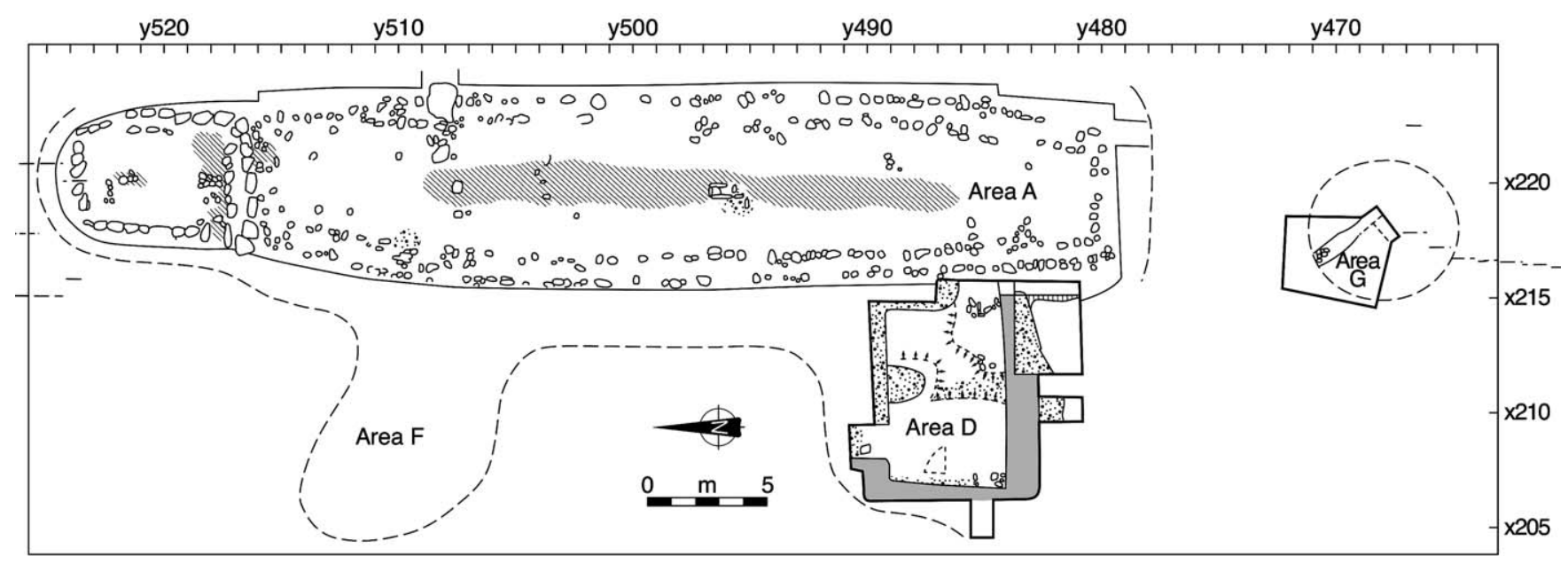

Fig. 2. The landnám age site at Hofstaðir, showing the long house (Area A), and the pit house (Area G) which is infilled by midden stratigraphy.

profiles (Fig. 3). The upper ' 5 ' series is a $10-15 \mathrm{~cm}$ thick light coloured ash-like deposit (10YR 8/4) with thin lenses of darker ash-like material (10YR 2/1) and some pebbles. The ' 6 ' series, with a Munsell colours range from 10YR $2 / 1$ to $10 \mathrm{YR} 7 / 3$, is much more mixed than either ' 5 ' or ' 7 ' below it and has been interpreted as the result of a series of small dumping events from a variety of sources. The ' 7 ' series is a thick deposit of ash-like material (10YR 3/1-10YR 6/1) with lenses of charcoal. At the base it is mixed with the ' 8 ' series, interpreted as turf wall collapse, and which represents the earliest phase of in-filling after the abandonment of the pit house. Ash residue materials at the Hofstadir site have also been observed as part of floor layers, and as minor accumulations in adjacent early hay fields associated with the site, but this study is confined to the major ash residue accumulations in the early pit house. Excavation confirms that Area A and Area G structures post-date the deposition of 10th century tephra provisionally called V 950 [29], and were abandoned before the fall of the 1104/1158 AD Hekla tephra [14]. Three bone samples (Bos taurus dom.) from the Area $G$ deposits were subject to radiocarbon (AMS) assay of the bone collagen (extracted with alkali) and give measured conventional radiocarbon ages (years $\mathrm{BP} \pm 1 \sigma$ ) of $1120 \pm 40$ (context 4), 1170 \pm 40 (context 6n) and $1130 \pm 40$ (context 8) (Table 1). The structural and chronological evidence from Hofstaðir thus indicates that this is a high status site with midden deposits from the late landnám period.

The site at Sveigakot is located to the south of Lake Mývatn in Mývatnssveit (Fig. 1) on the Pleistocene Palagonite Formation and is found on eroding aeolian sands with little or no vegetation [19]. Excavation has so far identified a small Viking-age long house (Area S), a small pit house filled with bone deposits (Area T) and a sheet midden stratigraphy (Area M) of some $25 \mathrm{~cm}$ in thickness between aeolian deposits (Fig. 4; [40]). Radiocarbon and structural evidence suggest that the site was entirely abandoned by the late AD 1100s [40]. Munsell colours within the midden stratigraphy range from 10YR 2/1 to $10 \mathrm{YR} 10 \mathrm{YR} 2 / 2$, with texture classes of fine sandy silt loam and silt loam, and $\mathrm{pH}$ values of between 6.1 and 6.8 (Fig. 5). The midden deposits post-date the landnám tephra from $\mathrm{AD} 871 \pm 2$ [17], and can be subdivided chronologically into pre- and post$\mathrm{V} \sim 950$ tephra phases (Fig. 5). To assist in further defining the chronology of Area M, three bone samples extracted from the midden stratigraphy have been used for AMS radiocarbon assay of the collagen (extracted with alkali). These give measured radiocarbon ages (years $\mathrm{BP} \pm 1 \sigma$ ) of $1120 \pm 40$ (context 12), $1090 \pm 40$ (context 10) and 1110 \pm 40 (context 10) (Table 1). Although artefact and faunal assemblages from the site suggest some characteristics of high status [40], its structural characteristics indicate that it is representative of a more marginal, secondary, site. Midden stratigraphies are associated with the landnám period and are chronologically comparable with those at the Hofstadir, making comparison of fuel residue utilisation between the two sites possible.

\subsection{Thin sections: field sampling, thin section manufacture and slide description}

Representative, undisturbed sediment samples from the midden stratigraphies at Hofstaðir and Sveigakot were collected in Kubiena tins. Vertical samples from Hofstadir were obtained from profile faces in three separate sections (G106a - three samples, G108-6 samples and G109 - five samples; Fig. 3), giving a total of 14 samples from the cultural deposits. Cultural deposit thickness was considerably less (up to $25 \mathrm{~cm}$ ) at Sveigakot, and here samples were collected horizontally 

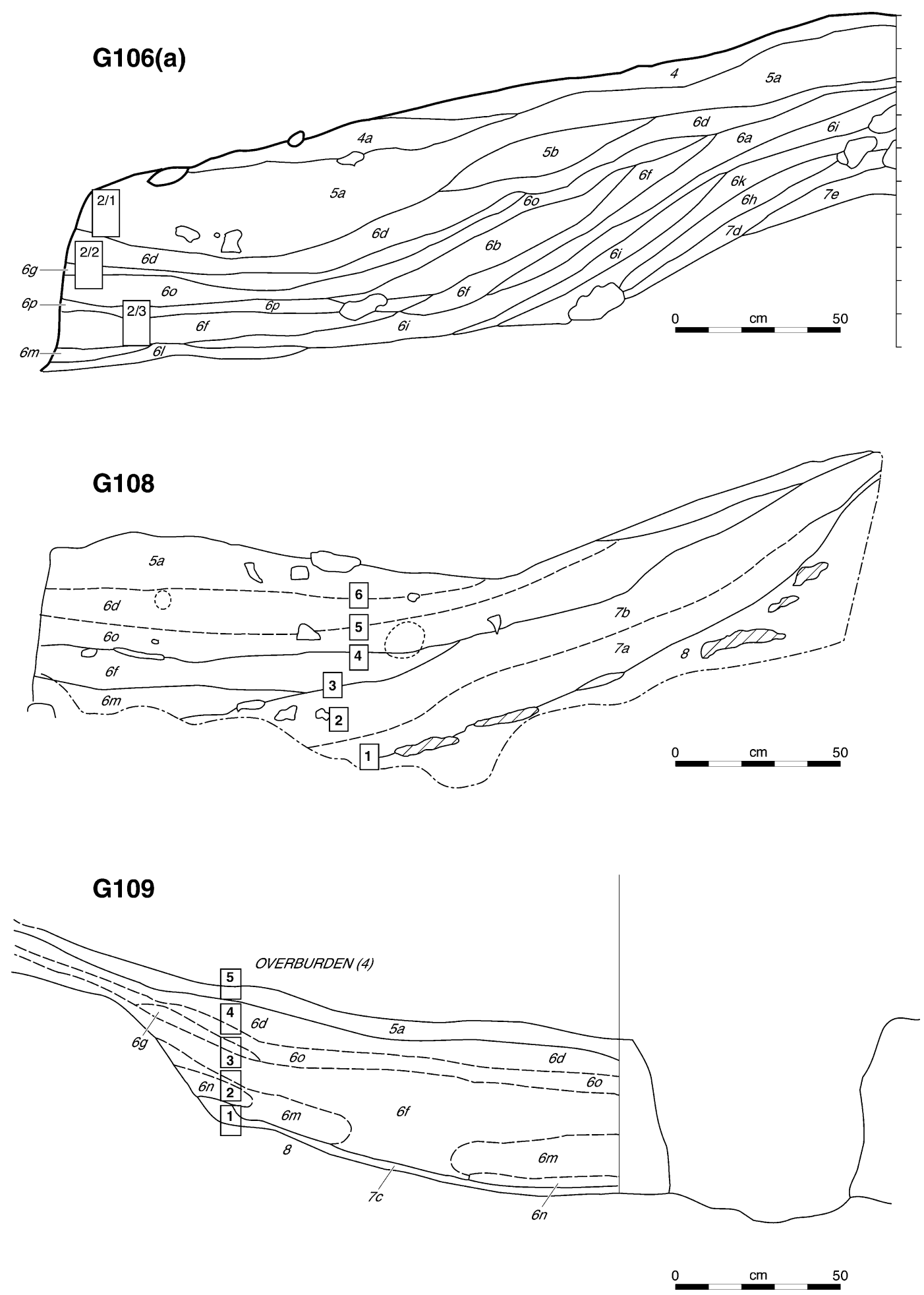

Fig. 3. Midden stratigraphies of Area G, Hofstaðir, showing thin section sample locations, with contexts 5 (upper context of the stratigraphy), 6, 7 and 8 (lower context of the stratigraphy); (a) section 106a, (b) section 108 and (c) section 109.

from three faces of the exposed sheet midden $(\mathrm{M} / \mathrm{sp}-$ five samples, $\mathrm{M} / \mathrm{wp}$ - five samples, M/ws-ns-four samples; Fig. 5). Based on field observation of site stratigraphies, these samples gave the widest possible range of deposit types. Thin sections of control materials and archaeological sediments were prepared following the procedures of Murphy [25]. Water was removed from archaeological sediment samples by acetone exchange and confirmed by specific gravity measurement. All samples were impregnated using polyester crystic resin 
Table 1

Radiocarbon ages of bone collagen (Bos taurus dom.) from midden stratigraphies at Hofstaðir (Area G) and Sveigakot (Area M)

\begin{tabular}{|c|c|c|c|c|c|c|}
\hline & Sample type & $\begin{array}{l}\text { Stratigraphic } \\
\text { context }\end{array}$ & $\begin{array}{l}\text { Lab code } \\
\text { no. }\end{array}$ & $\begin{array}{l}\text { Conventional radio-carbon age } \\
(\mathrm{yr} \text { B. } \mathrm{P} \pm 1 \sigma)\end{array}$ & $\delta^{13} \mathrm{C} \% 0$ & $\begin{array}{l}\text { Calibrated age ranges } \\
\text { (yr AD to } 2 \sigma \text { ) }\end{array}$ \\
\hline \multirow[t]{3}{*}{ Hofstaðir } & Bone collagen (B. taurus) & 004 & Beta 149403 & $1120 \pm 40$ & -21.7 & $\begin{array}{l}\text { AD } 810-840 \text { and } \\
\text { AD } 860-1000\end{array}$ \\
\hline & Bone collagen (B. taurus) & 006 & Beta 124004 & $1170 \pm 40$ & -21.4 & AD 780-980 \\
\hline & Bone collagen (B. taurus) & 008 & Beta 149404 & $1130 \pm 40$ & -21.5 & AD 790-1000 \\
\hline \multirow[t]{3}{*}{ Sveigakot } & Bone collagen (B. taurus) & 012 & Beta 134144 & $1120 \pm 40$ & -21.0 & $\begin{array}{l}\text { AD } 815-840 \text { and } \\
\text { AD } 855-1005\end{array}$ \\
\hline & Bone collagen (B. taurus) & 010 & Beta 134145 & $1090 \pm 40$ & -19.3 & AD $880-1015$ \\
\hline & Bone collagen (B. taurus) & 010 & Beta 134146 & $1110 \pm 40$ & -21.0 & AD $870-1005$ \\
\hline
\end{tabular}

Calibration: [35-37].

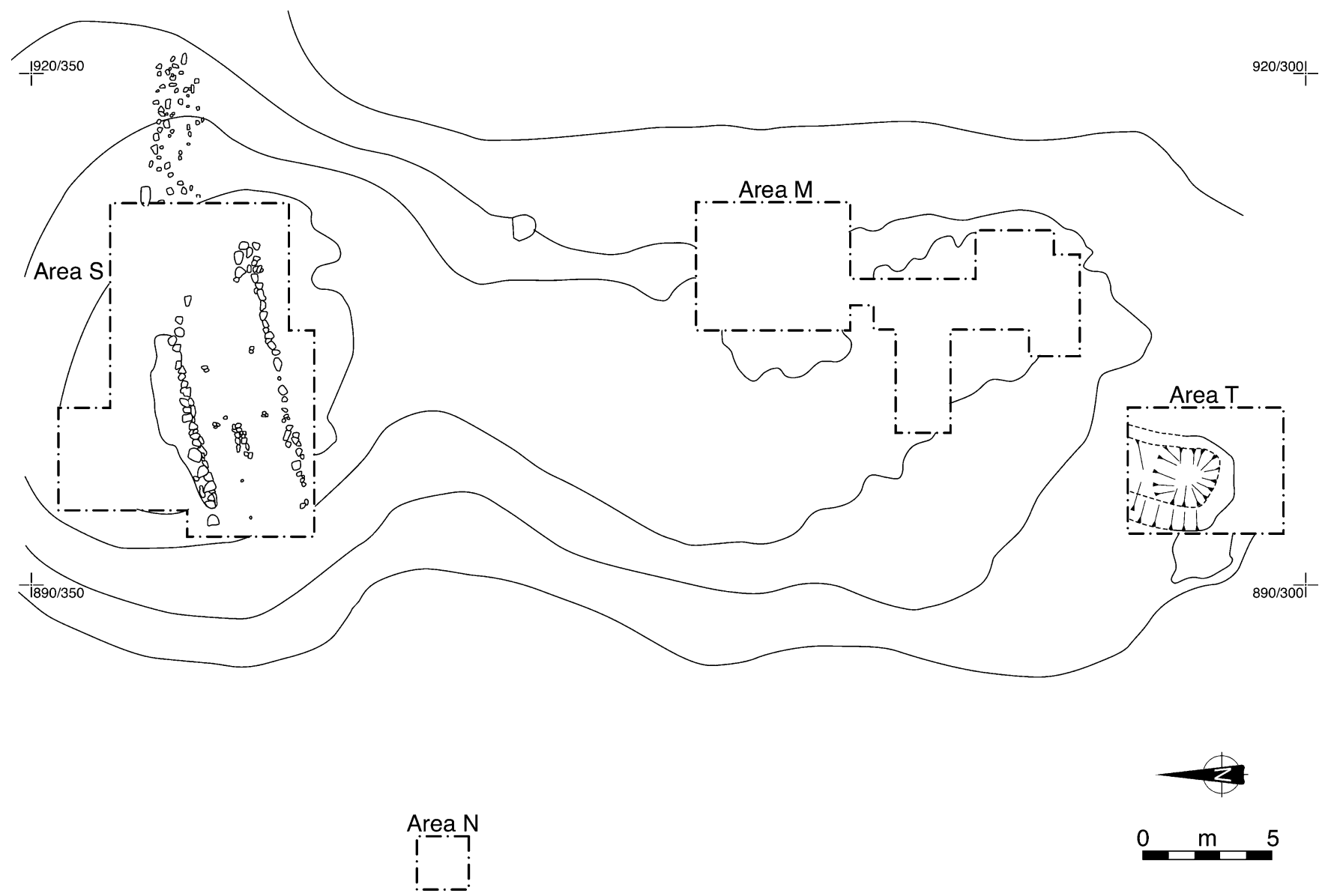

Fig. 4. Site plan of the landnám age site at Sveigakot, showing the small longhouse (Area S), the pit house (Area T) and the sheet midden deposits (Area M).

and a catalyst. The mixture was thinned with acetone and a standard composition of $180 \mathrm{ml}$ resin, $1.8 \mathrm{ml}$ catalyst and $25 \mathrm{ml}$ acetone used for each Kubiena tin. No polymerisation accelerator was used. The sample was impregnated under vacuum to ensure outgassing of the soil. The blocks were then cured for three to four weeks finishing with 4 days in a $40{ }^{\circ} \mathrm{C}$ oven. Blocks were sliced, bonded to a glass slide and precision lapped to $30 \mu \mathrm{m}$, with cover-slipping completing manufacture of the section. Thin sections were described using an Olympus BH-2 petrological microscope, following the internationally accepted terminology in the Handbook for Soil Thin Section Description [8]. For fuel ash residues, this allowed systematic description of coarse 
M / WS - NS

902/312

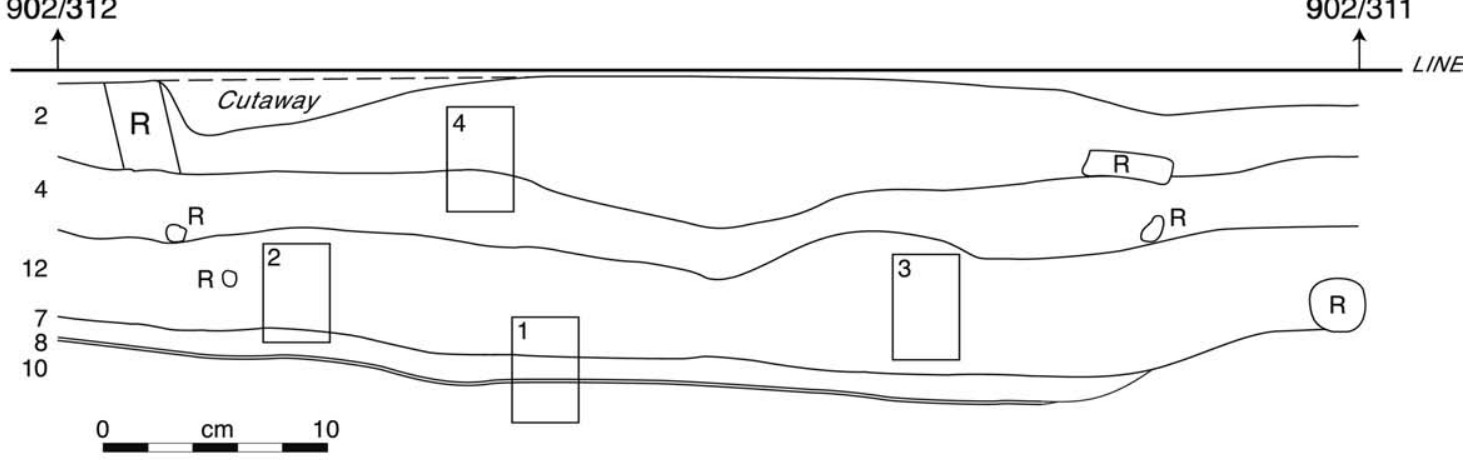

2. 10YR 2/1; Fine sandy silt loam; Fine granular structure

4. 10YR 3/1; Fine sandy silt loam; Fine granular structure

12. 10YR $2 / 2$ with Few $10 \mathrm{YR} 3 / 2$ and $10 \mathrm{YR} 3 / 1$; Lensed; Silty loam; Fine granular structure

7. Tephra horizon 10YR 5/1; Fine Loamy sand; Fine angular blocky (AD 950)

8. 7.5 YR $3 / 3$

10. 7.5YR 3/2; Fine loamy sand; Fine angular blocky

R Rock

\section{$\mathrm{M} / \mathrm{SP}$}

$0 \stackrel{900 / 314 \quad 899 / 314}{\longmapsto}$

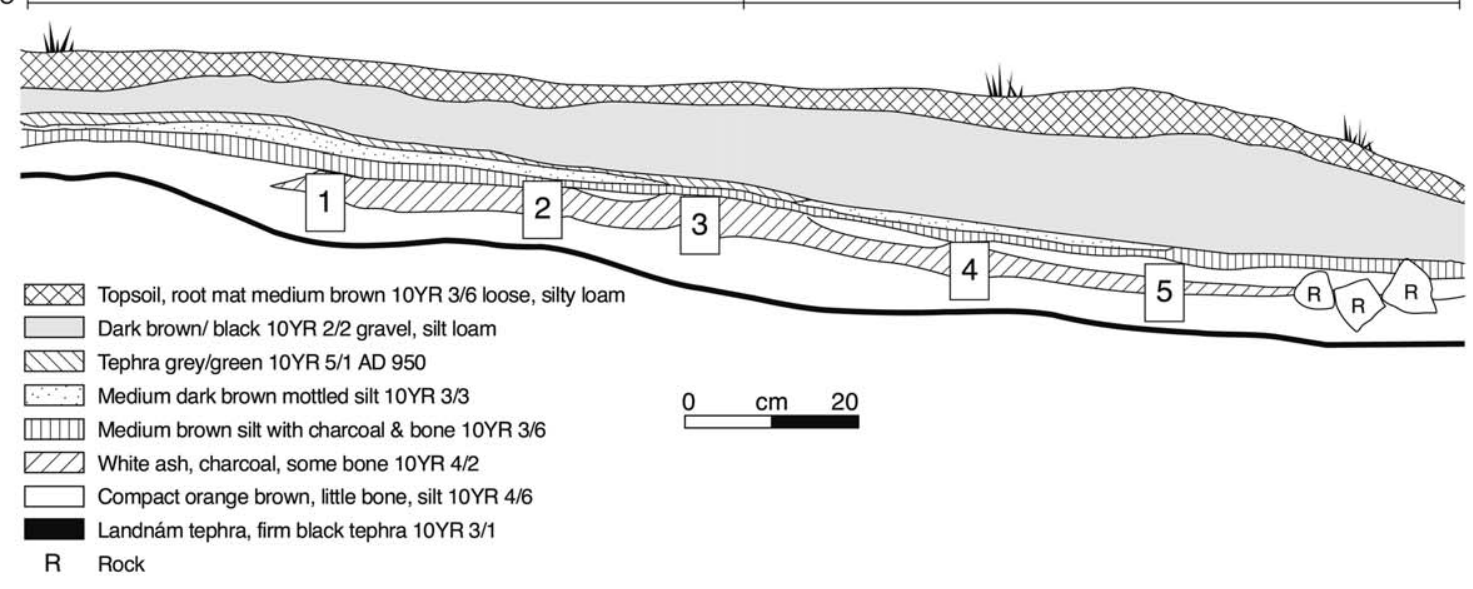

M / WP

$898 / 314$

$898 / 316$

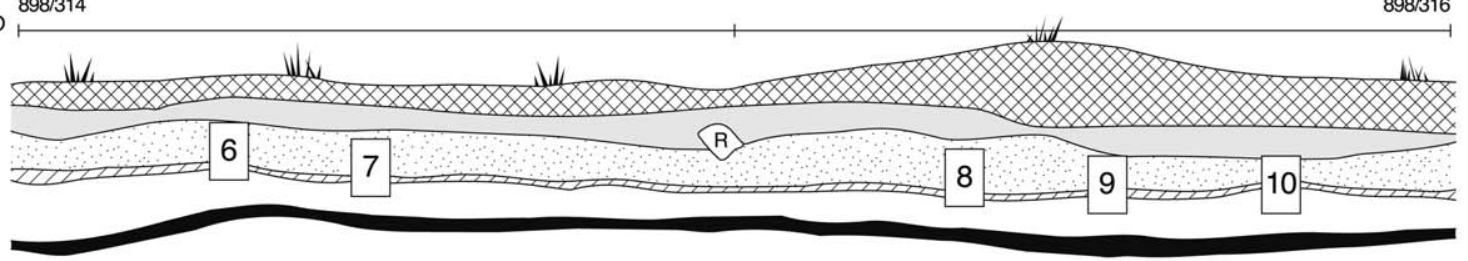

Wopsoil, root mat medium brown 10YR $3 / 6$ silty loam

Dark brown/ black 10YR 2/2 some gravel, silt

Medium dark brown mottled with silt, lots of bone

\begin{tabular}{lll}
$0 \quad \mathrm{~cm} \quad 20$ \\
\hline
\end{tabular}

ZZ 10YR 2/2 dark ash layer, lots of charcoal, some bone

Compact 10YR $4 / 4$ with $4 / 6$ silt

Landnám tephra, firm black tephra 10YR 3/1

R Rock

Fig. 5. Midden stratigraphies, Area M, Sveigakot, showing thin section sample locations. Samples from (a) M/ws-ns are predominately from the less frequently occurring deposits above the c. AD 950 Veiðivötn tephra; samples from (b) M/sp and (c) M/wp are from deposits below the c. AD 950 Veiðivötn tephra. 
mineral material, fine mineral material, organic material and groundmass $\mathrm{b}$ fabric. A range of magnifications $(\times 10-\times 400)$ and constant light sources (plane polarised-ppl, cross-polars - xpl, circular polarisedcpl and oblique incident-oil) were used to obtain detailed descriptions, and these were recorded in semiquantitative summary tables.

\subsection{Image analysis of thin sections}

Image analyses of control and archaeological thin sections were undertaken independently from conventional micromorphological description. Thin sections of the combusted $\left(400{ }^{\circ} \mathrm{C} ; 800{ }^{\circ} \mathrm{C}\right)$ humified peat material, mineral-rich turf material material, sheep dung, cow dung, birch wood and willow wood were prepared to a measured $30 \mu \mathrm{m}$ uniform section thickness before the slide coverslip was applied. Colour characteristics using constant illumination (plane polarised, crossed polars and oblique incident) were examined using an image analysis system comprising of a polarising microscope (BX50, Olympus Optical Co., Japan), 3-CCD chip video camera (HV-10, Hitachi Densai Ltd, Japan) with software control (AnalySIS, Soft Imaging $\mathrm{GmbH}$, Münster). An area of $1.5 \times 1.5 \mathrm{~cm}$ was examined at high resolution for each sample using the method developed by Adderley et al. [1]. To establish the range and distribution of colour properties within these materials, five thousand spot measurements, each $3 \times 3 \mu \mathrm{m}$, were made within this area at randomly allocated positions. The spectral characteristics for each spot were recorded and summary statistical data obtained.

From the analysis of the reference materials a set of image segmentation thresholds were developed to allow quantitative image analysis. Two types of material are considered: features and matrix. The first set of materials contains features that are micromorphologically discrete. This includes heated mineral, calcitic material and carbonised and non-carbonised materials. These all have distinct boundaries and can be identified and semi-quantified readily using conventional micromorphological methods. The second set of materials is those that are diffuse and contribute to the matrix, such as reddened and yellowed turf materials observed under oblique incident light. These matrix features can be described but are not quantifiable using conventional micromorphological methods. A further advance over conventional assessment of the slide is that areal contribution of both the discrete features and the matrix components can be assessed together. Using a combination of uniform slide production, uniform illumination [1], and a correlation to reference materials has allowed the contribution to the sediment matrix of these materials to be considered quantitatively for the first time.
The archaeological sediment samples were analysed with micro-horizons assigned by standard visual comparison in plane polarised light, using both morphological and colour criteria [13]. Within each micro-horizon, an image of a representative area of $1.0 \times 1.0 \mathrm{~cm}$ was captured, although some micro-horizons could not be sampled because the area of slide was too small to sample reliably, or because slides could not be manufactured to precisely $30 \mu \mathrm{m}$. (A discussion of the significance of slide thickness in image analyses of thin sections is found in [1].) Using the thresholds developed from the reference materials, the micro-horizons assigned to the thin sections from the Hofstadir and Sveigakot midden deposits were analysed. For each analysis, spectral and size variables were recorded.

\section{Results and Discussion}

\subsection{Micromorphology of experimentally combusted materials}

Residues from combusting peat and mineral-based turf material at $400{ }^{\circ} \mathrm{C}$ are clearly characterised in thin section by rubified (reddened) fine mineral material observed in oblique incident light (Table 2; [10]). Discrimination between peat and mineral-based turf is evident in the very few and few occurrences respectively, of rubified coarse mineral material. Such rubification of coarse and fine mineral material is caused by structural disruption during heating and resulting segregation of iron oxides. The few, meso-sized charcoal fragments is also indicative and accords with the recent experimental observations of Umbanhower and McGrath [38] highlighting distinctions between wood, leaf and grass charcoals. Silica phytolith and diatom attributes can also be used to discriminate between peat turf and mineralbased turf. In peat, frequent phytoliths and few diatoms are observed, contrasting with the very few phytoliths and very few diatoms of the mineral-rich turf material. At $800{ }^{\circ} \mathrm{C}$, organic material has completely combusted in both peat and mineral-based turf materials and the fine mineral material is characteristically yellow in oblique incident light. Very few silica phytoliths and diatoms are, however, more obvious in peat residues.

At combustion temperatures of $400{ }^{\circ} \mathrm{C}$ wood material can be distinguished from other materials by its distinctive crystallitic groundmass $b$ fabric dominated by calcite and by the frequent occurrence of macro-sized black charcoal fragments (Table 2 [12]; [27]. The calcite crystals, which are grey in oblique incident light, have irregular surfaces, are poorly preserved and do not retain structural characteristics. These, although likely to be calcitic pseudomorphs derived from specific plantsource calcium oxalates, cannot be used as a species indicator $[5,9]$. A distinction between willow $(S$. lanata $)$ and birch (B. pubescens) wood material is, however, 
Table 2

Micromorphological descriptions of ash residues from historical fuel resources-woods, turves and animal manures-combusted at $400{ }^{\circ} \mathrm{C}$ and $800{ }^{\circ} \mathrm{C}$

\begin{tabular}{|c|c|c|c|c|c|c|}
\hline & Peats & Mineral-based turf & Willow wood (Salix lanata) & $\begin{array}{l}\text { Birch wood (Betula } \\
\text { pubescens) }\end{array}$ & Cow dung & Sheep dung \\
\hline \multirow[t]{8}{*}{$400{ }^{\circ} \mathrm{C}$} & Coarse mineral material & Coarse mineral material & Coarse mineral material & $\begin{array}{l}\text { Coarse mineral } \\
\text { material }\end{array}$ & Coarse mineral material & Coarse mineral material \\
\hline & $\begin{array}{l}\text { Frequent silica phytoliths, few } \\
\text { silica diatoms; very few red } \\
\text { heated minerals, very few } \\
\text { tephra; very few quartz; very } \\
\text { few irregular calcites }\end{array}$ & $\begin{array}{l}\text { Very few silica phytoliths (all } \\
\text { grass); very few silica diatoms; } \\
\text { few red heated minerals; few } \\
\text { tephra; few quartz; very few } \\
\text { irregular calcites }\end{array}$ & None observed & None observed & None observed & $\begin{array}{l}\text { Very few heated red } \\
\text { minerals; very few } \\
\text { tephra; very few } \\
\text { irregular calcites }\end{array}$ \\
\hline & Fine mineral material & Fine mineral material & Fine mineral material & $\begin{array}{l}\text { Fine mineral } \\
\text { material }\end{array}$ & Fine mineral material & Fine mineral material \\
\hline & $\begin{array}{l}\text { Dominant dark brown (ppl) } \\
\text { and red (oil) }\end{array}$ & $\begin{array}{l}\text { Frequent brown (ppl) and } \\
\text { red/orange (oil) }\end{array}$ & $\begin{array}{l}\text { Dominant grey and dark brown } \\
\text { (ppl); grey and orange (oil) }\end{array}$ & $\begin{array}{l}\text { Very dominant grey } \\
\text { (ppl); grey and } \\
\text { orange (oil) }\end{array}$ & None observed & $\begin{array}{l}\text { Very dominant, light } \\
\text { brown (ppl); grey } \\
\text { crystallitic with few } \\
\text { black materials (oil); } \\
\text { fragmented }\end{array}$ \\
\hline & Organic material & Organic material & Organic material & Organic material & Organic material & Organic material \\
\hline & $\begin{array}{l}\text { Occasional black (ppl and oil); } \\
\text { carbonised }\end{array}$ & $\begin{array}{l}\text { Occasional black and dark brown } \\
\text { (ppl) and (oil); carbonised }\end{array}$ & $\begin{array}{l}\text { Frequent black, various shapes, } \\
\text { with occasional porous } \\
\text { structures, carbonised; and } \\
\text { frequent, linear fibrous brown } \\
\text { (ppl and oil), partially carbonised }\end{array}$ & $\begin{array}{l}\text { Frequent, black } \\
\text { (ppl and oil), } \\
\text { rodlike and } \\
\text { sub-rounded, } \\
\text { carbonised }\end{array}$ & $\begin{array}{l}\text { Very dominant, black (ppl } \\
\text { and oil); common internal } \\
\text { void space, smooth and } \\
\text { rough serrate; fibrous and } \\
\text { fragmented }\end{array}$ & None observed \\
\hline & Groundmass b fabric & Groundmass b fabric & Groundmass b fabric & $\begin{array}{l}\text { Groundmass b } \\
\text { fabric }\end{array}$ & Groundmass b fabric & Groundmass b fabric \\
\hline & Faintly stipple speckled & Faintly stipple speckled & Crystallitic micro-fine & $\begin{array}{l}\text { Crystallitic } \\
\text { micro-medium }\end{array}$ & Isotropic, black & Stipple speckled \\
\hline \multirow[t]{8}{*}{$800^{\circ} \mathrm{C}$} & Coarse mineral material & Coarse mineral material & Coarse mineral material & $\begin{array}{l}\text { Coarse mineral } \\
\text { material }\end{array}$ & Coarse mineral material & Coarse mineral material \\
\hline & $\begin{array}{l}\text { Dominant silica phytoliths, } \\
\text { few silica diatoms; frequent } \\
\text { red heated minerals; very few } \\
\text { irregular calcites }\end{array}$ & $\begin{array}{l}\text { Very few silica phytoliths (all } \\
\text { grass); very few silica diatoms; } \\
\text { frequent red heated minerals; very } \\
\text { few irregular calcites }\end{array}$ & None observed & None observed & $\begin{array}{l}\text { Very few red heated mineral; } \\
\text { very few tephra; very few } \\
\text { irregular calcites }\end{array}$ & $\begin{array}{l}\text { Very few heated } \\
\text { minerals }\end{array}$ \\
\hline & Fine mineral material & Fine mineral material & Fine mineral material & $\begin{array}{l}\text { Fine mineral } \\
\text { material }\end{array}$ & Fine mineral material & Fine mineral material \\
\hline & $\begin{array}{l}\text { Frequent light brown (ppl) } \\
\text { and yellow (oil) }\end{array}$ & $\begin{array}{l}\text { Frequent light brown (ppl) and } \\
\text { yellow (oil) }\end{array}$ & $\begin{array}{l}\text { Very dominant; pale brown (ppl) } \\
\text { and light grey (oil) }\end{array}$ & $\begin{array}{l}\text { Very dominant; } \\
\text { dark brown (ppl) } \\
\text { and light grey (oil) }\end{array}$ & $\begin{array}{l}\text { Very dominant, grey (ppl) } \\
\text { and white/grey (oil); fibrous }\end{array}$ & $\begin{array}{l}\text { Very dominant, grey } \\
\text { (ppl); white/grey (oil); } \\
\text { fragmented }\end{array}$ \\
\hline & Organic material & Organic material & Organic material & Organic material & Organic material & Organic material \\
\hline & None observed & None observed & None observed & None observed & None observed & None observed \\
\hline & Groundmass b fabric & Groundmass b fabric & Groundmass b fabric & $\begin{array}{l}\text { Groundmass b } \\
\text { fabric }\end{array}$ & Groundmass b fabric & Groundmass b fabric \\
\hline & Faintly stipple speckled & Faintly stipple speckled & Crystallitic micro-fine clustered & $\begin{array}{l}\text { Crystallitic } \\
\text { micro-fine clustered }\end{array}$ & Faintly stipple speckled & Stipple speckled \\
\hline
\end{tabular}




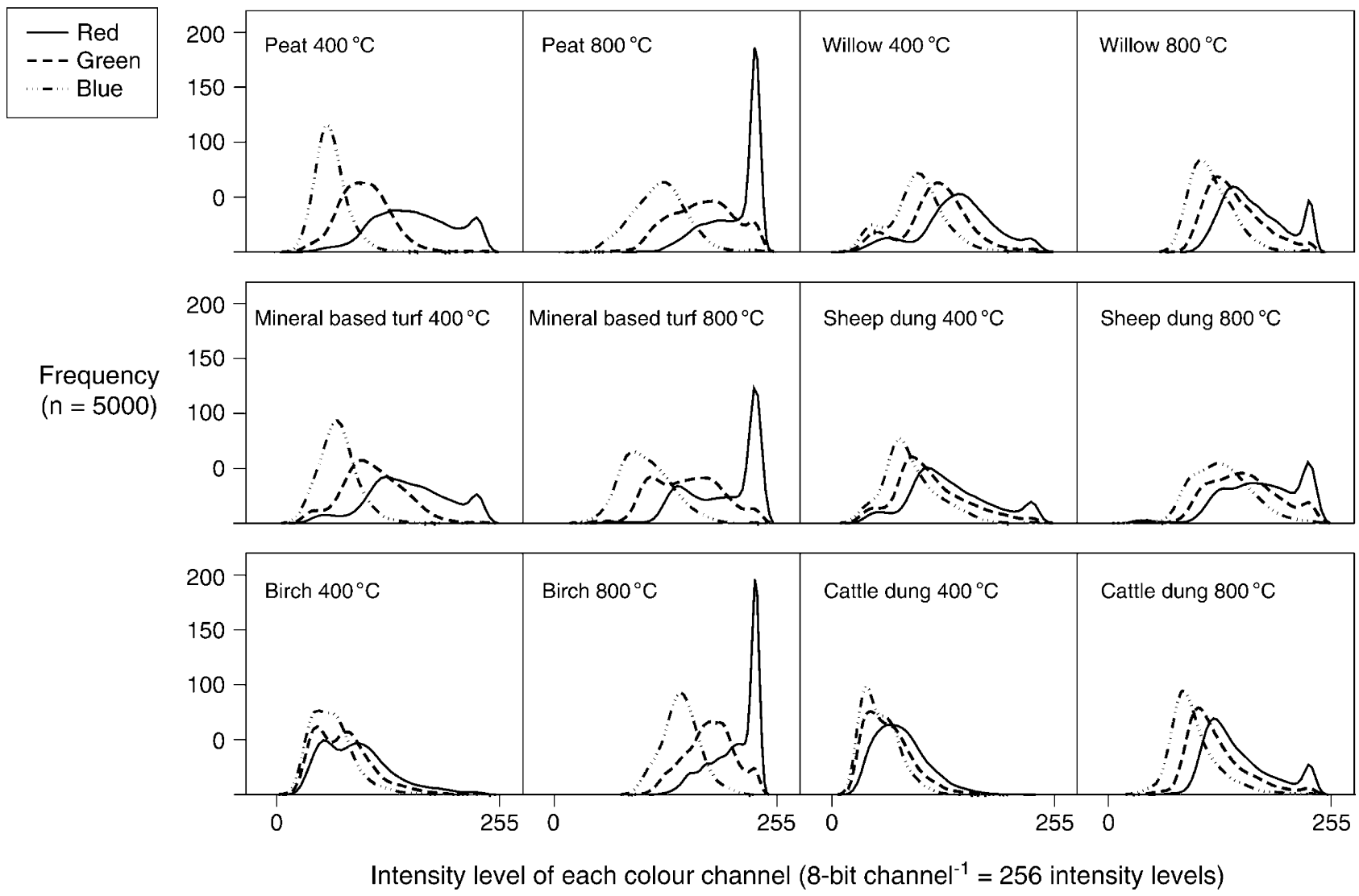

Fig. 6. Histograms of spectral properties (RGB; 8 bit/channel) of experimental combusted fuel materials.

suggested at by their related distribution to charcoal materials. Willow crystallitic $b$ fabric material is classified as micro-medium with clustering of calcites along the edges of the dark brown fibrous charcoal material, with birch classified as micro-coarse, but not directly interfacing with charcoal. Further distinctions between willow and birch ash residues combusted at $400{ }^{\circ} \mathrm{C}$ are suggested, with willow ash residue contains brown fibrous charcoals that are absent from birch ash residues. At $800^{\circ} \mathrm{C}$ crystallitic b fabrics are still in evidence as a distinguishing characteristic of wood ash, although paler and clustered, perhaps fused; there is however, no visually observable distinction between willow and birch materials.

Animal dungs combusted at $400{ }^{\circ} \mathrm{C}$ also exhibit distinctive micromorphological characteristics (Table 2). Burnt residues of cow dung are characterised by black, isotropic organic material with surfaces that range from smooth to rough serrate. In contrast, burnt sheep dung residues are characterised by fine mineral material, which is light brown (plane polarised light) and grey (oblique incident light) in colour. Very few coarse mineral grains are evident in the sheep dung ash residues, reflecting rangeland grazing; very few calcitic spherulites are also evident, with a concentric pattern distinct from the calcitic material found in much of the wood ash residues. After combustion at $800{ }^{\circ} \mathrm{C}$ cow dung and sheep dung residues are similar, with fine mineral material of grey colours in plane polarised light and white/grey colours in oblique incident light very dominant. Subtle distinctions in fine mineral material are evident however; fibrous in cow dung ash residues and more fragmented and crystallitic in sheep dung ash residues that may reflect differences in diet.

\subsection{Image analysis of experimentally combusted fuel materials; definition of thresholds}

Results from the analysis of 5000 sample points in each experimentally combusted fuel material are presented in Fig. 6, showing the relative intensity of a spectral distribution for each of three separate colour axes (Red, Green, Blue: RGB). There are clear separations between the turf/peat, wood and animal dung matrix materials, particularly in the red axes. A two-way separation was developed: between material types (wood vs. peat and turf) and between burning temperatures (i.e. $400{ }^{\circ} \mathrm{C}, 800^{\circ} \mathrm{C}$ ). In addition to the image analysis thresholds derived from reference materials, uncarbonised materials were quantified using a set of thresholds based on peat and turf material fragments previously identified in thin section. 
There is a distinct separation of the mineral-rich turf material component from the peat materials based on the rubified grains found in each sample. Feature counts were obtained for the rubified mineral grains; it was found empirically that these counts were a reliable indicator of heating, and more precise relative to area based measurements since there is a wide range of rubified mineral material grain sizes. Testing of the reference samples allows a threshold value $\left(>19 \mathrm{~cm}^{-2}\right)$ to be ascribed to the number of rubified mineral grains found in mineral-rich turf material. Distinction between $800{ }^{\circ} \mathrm{C}$ and $400{ }^{\circ} \mathrm{C}$ combustion of peat/turf materials are evident in the relative distribution of yellow and reddened matrix materials respectively.

The experimentally combusted wood materials reveal a large amount of calcitic material, which can be readily used as a quantitative indicator of the wood-fuel residue inputs, and thresholds based on the colour, especially the colour intensity, of the calcitic material seen in oblique incident illumination were developed. No significant $(P>0.05)$ quantitative differences were found in the sizes of the individual calcitic features found in the birch and willow materials at either $400{ }^{\circ} \mathrm{C}$ or $800{ }^{\circ} \mathrm{C}$ burning temperatures. The carbonised material threshold values were based on black fragments, which would be normally attributed as charcoal when examined optically in thin-section. The carbonised materials are normally attributed to burnt peat and turf fragments, or to wood charcoal. The differences between these were examined by considering the size of the carbonised material found in the reference materialsturf, peat, willow and birch-burnt at $400{ }^{\circ} \mathrm{C}$. There was no significant difference $(P>0.05)$ in the particle size of the carbonised fragments in the wood samples, and with a relatively low sample size for other potential evidence such as analysis of holes in the carbonised fragments, no distinction between tree species was made. However, the size of the carbonised materials can take the peat and turf vs. wood distinction further. The mean area of the individual carbonised particles, in conjunction with the overall area of the section sample, gives an indication of the relative dominance of individual particles on the percentage area results. A low areal percentage and a high mean particle size suggests that the carbonised material in such a section is dominated by a small number of large fragments.

\subsection{Micromorphology and quantitative image analyses of fuel residues in midden deposits}

Tables 3 and 4 provide summary micromorphology descriptions of thin sections from Hofstadir and Sveigakot midden stratigraphies. Figs. 7 and 8 show the results of image analyses based on the defined threshold criteria. For Hofstaðir, profiles G108 and G109 are spatially arranged corresponding to both profile position and micro-horizon (Fig. 3). No image analysis data is reported for profile G106 since the section thickness was found to be variable across each slide. The Sveigakot stratigraphies (Fig. 5) are laterally arranged and these data are reported in Table 5.

Micromorphological characteristics of experimentally combusted material were used to assist in the interpretation of fuel residue features in thin sections from Hofstaðir and Sveigakot midden stratigraphies. Preliminary observation of these thin sections established coarse mineral material, fine mineral material, organic material and groundmass $b$ fabrics as having the same type of micromorphological attributes as the experimentally combusted material, although there is mixing of different ash residue attributes. The experimental analyses provide, therefore, a basis from which to interpret fuel utilisation at the study sites, with micromorphology and related image analyses enabling the separation of mixed ash residue deposits.

Care is required in differentiating between fuel ash residues and other debris within the midden, which may resemble ash residues. Calcitic material (very few) derived from shell is evident in the midden thin sections, but apart from ash residues, the main constituents of the midden stratigraphy are uncarbonised amorphous brown organic materials (very few to dominant)interpreted as turf construction waste-and animal and fish bone fragments (very few to frequent). Preliminary observation of midden deposit thin sections also demonstrates the relatively undisturbed nature of the deposits at both Hofstaðir and Sveigakot; evidence of bioturbation and cryoturbation is rare or non-existent, reflected in the finely stratified nature of the deposits. Consistent evidence of aeolian deposition in the midden stratigraphy at Sveigakot highlights the marginality and dynamic nature of the environment associated with this site, in marked contrast to the Hofstaðir site where evidence of aeolian deposition within the midden stratigraphy is limited (Tables 3 and 4).

Red, fine mineral material colours (oblique incident light) associated with carbonised organic materials and phytoliths can be interpreted as peat and mineral-based turf ash residues from low temperature combustion. Very few and few occurrences of heated coarse mineral material, associated with the red fine mineral material, can separate peat and mineral based turf residues respectively (Tables 3 and 4; Figs. 7-9a). At Hofstaðir, there is evidence of low-temperature mineral-rich turf material as residues throughout the midden stratigraphies, from the beginning of deposition to its cessation, but particularly in the lower horizons where there is a relatively large number of rubified coarse minerals. As there is no micromorphological evidence to suggest that mineral-based turf material was combusted at high temperatures, it is possible to suggest that this was a 
Table 3

Summary micromorphological descriptions of thin sections from Hofstaðir, profiles 108, 109 and 106a

\begin{tabular}{|c|c|c|c|c|c|c|c|c|c|c|c|c|c|c|c|}
\hline \multirow[t]{2}{*}{ Section } & \multirow[t]{2}{*}{ Micro-horizon } & \multicolumn{6}{|c|}{ Coarse mineral material } & \multicolumn{4}{|c|}{ Fine mineral material (oil) } & \multicolumn{3}{|c|}{ Organic material } & \multirow[t]{2}{*}{ Groundmass $b$ fabric } \\
\hline & & $\stackrel{N}{\vec{Z}}$ & $\frac{\frac{\pi}{0}}{\frac{\pi}{\pi}}$ & 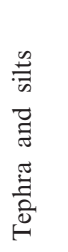 & 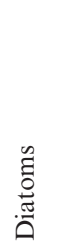 & $\begin{array}{l}\stackrel{0}{D} \\
\text { 竞 } \\
\text { 竞 }\end{array}$ & 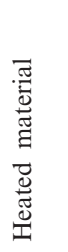 & $\begin{array}{l}\ddot{\Xi} \\
\simeq\end{array}$ & $\frac{z}{0}$ & 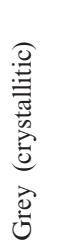 & 䓂 & 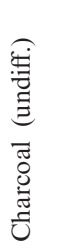 & $\begin{array}{l}\frac{a}{0} \\
\frac{\pi}{0} \\
0 \\
0 \\
0 \\
\frac{0}{2} \\
\frac{0}{0} \\
\vdots \\
\frac{1}{2}\end{array}$ & 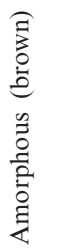 & \\
\hline \multirow[t]{5}{*}{$108 / 6$} & 1 & $*$ & $*$ & $*$ & & $*$ & $*$ & $*$ & & & & $* *$ & & $* * *$ & Stipple \\
\hline & 2 & ** & * & * & & & ** & $* *$ & * & & & $*$ & & * & Stipple \\
\hline & 3 & $*$ & $*$ & $*$ & & & $*$ & $*$ & & & & $* * *$ & & $* * *$ & Stipple \\
\hline & 4 & $*$ & $* *$ & $*$ & & $* *$ & $* *$ & $* * * *$ & $*$ & & & & $*$ & $*$ & Stipple \\
\hline & 5 & $*$ & $*$ & $*$ & & $*$ & $* *$ & $* * *$ & & & & $* * *$ & $*$ & & Stipple \\
\hline \multirow[t]{3}{*}{$108 / 5$} & 1 & $*$ & $*$ & $*$ & & $*$ & $* *$ & $* *$ & & & & $* *$ & $*$ & $* * *$ & Stipple \\
\hline & 2 & $*$ & $*$ & $*$ & & $* *$ & $*$ & $*$ & & & & $* * *$ & $*$ & $* * * *$ & Stipple \\
\hline & 3 & $*$ & $*$ & & & $*$ & $* *$ & $*$ & & & & $* *$ & $*$ & $* * *$ & Stipple \\
\hline $108 / 4$ & 1 & $*$ & $*$ & $*$ & & $*$ & $* *$ & $* * *$ & & & & $* * *$ & $*$ & & Stipple \\
\hline \multirow[t]{4}{*}{$108 / 3$} & 1 & $*$ & $*$ & $*$ & $*$ & $*$ & $* *$ & $* * *$ & & & & $* * *$ & $*$ & & Stipple \\
\hline & 2 & $*$ & & $* * * *$ & & & & & & & & & & & - \\
\hline & 3 & $*$ & $*$ & $*$ & & $*$ & $*$ & $* * *$ & & & & $* *$ & $*$ & $* * *$ & Stipple \\
\hline & 4 & $*$ & $*$ & $*$ & & $*$ & $*$ & $* *$ & & & & $*$ & $*$ & $* * *$ & Stipple \\
\hline \multirow[t]{4}{*}{$108 / 2$} & 1 & $*$ & $*$ & $*$ & & $*$ & $* *$ & $* *$ & & & & $* *$ & & $* *$ & Stipple \\
\hline & 2 & $*$ & $*$ & $*$ & & $*$ & $* *$ & $* * *$ & $*$ & & & & $*$ & $*$ & Stipple \\
\hline & 3 & * & * & * & & $*$ & $* *$ & $* *$ & & & & $* *$ & $*$ & $* * *$ & Stipple \\
\hline & 4 & $*$ & $*$ & $*$ & & $*$ & $* *$ & $* * * *$ & & & & & $*$ & & Stipple \\
\hline \multirow[t]{8}{*}{$108 / 1$} & 1 & $*$ & $*$ & $* *$ & & & & & & & $* * *$ & & & * & Stipple \\
\hline & 2 & $*$ & $*$ & $*$ & & $*$ & $* *$ & $* * * *$ & & & & $* *$ & $* *$ & & Stipple \\
\hline & 3 & $*$ & $*$ & $* * * *$ & & & & & & & & & & & - \\
\hline & 4 & * & * & $* *$ & & & & & & & $* * *$ & & & & Stipple \\
\hline & 5 & $*$ & $*$ & $* *$ & & & $* *$ & $* * *$ & $*$ & & $* * *$ & & & $*$ & Stipple \\
\hline & 6 & $*$ & $*$ & $*$ & & & $* * *$ & $* * * *$ & $* * *$ & & & & & $*$ & Stipple \\
\hline & 7 & * & * & $*$ & & & $* *$ & $* * * *$ & $*$ & & & & & * & Stipple \\
\hline & 8 & $*$ & $*$ & $* * * *$ & & & & & & & & & & & - \\
\hline \multirow[t]{2}{*}{$109 / 5$} & 1 & * & * & * & & $*$ & $* *$ & $* * *$ & * & & & $*$ & * & $*$ & Stipple \\
\hline & 2 & $*$ & $*$ & $*$ & & $*$ & $*$ & $*$ & & & & $* * *$ & $*$ & $* * *$ & Stipple \\
\hline \multirow[t]{3}{*}{$109 / 4$} & 1 & $*$ & $*$ & $*$ & & $*$ & $* *$ & $*$ & & & & $* * *$ & $*$ & $* * *$ & Stipple and crystallitic \\
\hline & 2 & $*$ & $*$ & $* * *$ & & $*$ & $* *$ & $* * *$ & $* *$ & & & & $*$ & $*$ & Stipple \\
\hline & 3 & $*$ & $*$ & $* *$ & & $*$ & $* *$ & $* *$ & $* *$ & & & $* *$ & $*$ & $* *$ & Stipple and crystallitic \\
\hline \multirow[t]{2}{*}{$109 / 3$} & 1 & * & ** & & & & $*$ & $* * *$ & $* * *$ & $* * * *$ & & & & $*$ & Crystallitic \\
\hline & 2 & $*$ & $*$ & $*$ & & $*$ & $* *$ & $* *$ & & $*$ & & $* * *$ & * & $* * *$ & Stipple and crystallitic \\
\hline \multirow[t]{4}{*}{$109 / 2$} & 1 & $*$ & $* *$ & $*$ & & $*$ & $*$ & $* *$ & $*$ & $* *$ & & $* * *$ & $*$ & $* * *$ & Stipple and crystallitic \\
\hline & 2 & * & $*$ & $* * *$ & & & & $*$ & $*$ & & & & & & - \\
\hline & 3 & * & $*$ & $*$ & & $*$ & $*$ & $* *$ & $*$ & $*$ & & $* * *$ & $*$ & $* * *$ & Stipple and crystallitic \\
\hline & 4 & $*$ & $*$ & $*$ & & $*$ & $* *$ & $* * *$ & $* *$ & $*$ & & $*$ & $*$ & $*$ & Stipple and crystallitic \\
\hline \multirow[t]{3}{*}{$109 / 1$} & 1 & * & $* *$ & * & & $*$ & $* *$ & $* * *$ & $*$ & $*$ & & * & * & * & Stipple and crystallitic \\
\hline & 2 & * & $*$ & * & & $*$ & $* * *$ & $* * *$ & $* *$ & $* *$ & & * & & * & Crystallitic \\
\hline & 3 & $*$ & $*$ & $*$ & & $*$ & $*$ & $* * *$ & $* * *$ & $*$ & & & $*$ & & Stipple and crystallitic \\
\hline $106 \mathrm{a} / 1$ & 1 & $*$ & $*$ & $*$ & & $*$ & $*$ & $* * *$ & & & & $* *$ & & & Stipple \\
\hline $106 \mathrm{a} / 2$ & 1 & * & $*$ & * & & * & $* *$ & $* *$ & * & & $* * *$ & $* * *$ & * & & Stipple and crystallitic \\
\hline
\end{tabular}


Table 3 (continued)

\begin{tabular}{|c|c|c|c|c|c|c|c|c|c|c|c|c|c|c|c|}
\hline \multirow[t]{2}{*}{ Section } & \multirow[t]{2}{*}{ Micro-horizon } & \multicolumn{6}{|c|}{ Coarse mineral material } & \multicolumn{4}{|c|}{ Fine mineral material (oil) } & \multicolumn{3}{|c|}{ Organic material } & \multirow[t]{2}{*}{ Groundmass $b$ fabric } \\
\hline & & $\stackrel{N}{\stackrel{\Xi}{Z}}$ & 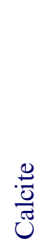 & 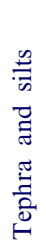 & 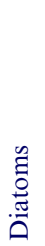 & $\frac{\stackrel{0}{E}}{\stackrel{0}{0}}$ & 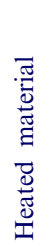 & $\overrightarrow{\ddot{d}}$ & $\frac{3}{20}$ & 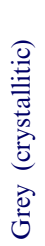 & 客 & 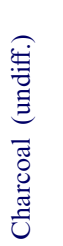 & 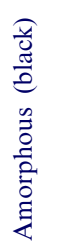 & 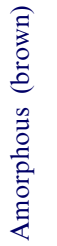 & \\
\hline $106 \mathrm{a} / 3$ & $\begin{array}{l}1 \\
2\end{array}$ & $\begin{array}{l}* \\
*\end{array}$ & $\begin{array}{l}* \\
*\end{array}$ & * & & $\begin{array}{l}* \\
*\end{array}$ & $\begin{array}{l}* * \\
* *\end{array}$ & $\begin{array}{l}* * \\
* *\end{array}$ & * & & $\begin{array}{l}* * * \\
* * *\end{array}$ & $\begin{array}{l}* * \\
* * *\end{array}$ & $\begin{array}{l}* * \\
*\end{array}$ & & $\begin{array}{l}\text { Stipple and crystallitic } \\
\text { Stipple and crystallitic }\end{array}$ \\
\hline
\end{tabular}

Frequency class refers to the area of section [8]. *Very few; $* *$ few; $* * *$ frequent/common; $* * *$ dominant/very dominant.

staple fuel resource during the settlement and consolidation period, and was likely to have been exploited for domestic heating, lighting and cooking activity. Evidence of low temperature peat combustion is more limited and is more consistently evident in the middle and upper horizons of the Hofstaðir midden stratigraphies. In contrast, the less frequently occurring yellow matrix colours lacking rubified coarse mineral materials are particularly evident in section G109 and G106 and indicating that peats were combusted at high temperatures throughout the formation of the midden (Fig. 9b). These observations suggest that much of the peat brought to the site as a fuel resource was primarily for 'industrial' activity. At Sveigakot a different pattern of fuel resource utilisation emerges. Here, as at Hofstaðir, there is evidence of substantial use of mineral-based turf for low temperature combustion, with large peaks in the post c. AD 950 stratigraphy. These observations serve to further emphasise the significance of this material as a staple of domestic fuel resource consumption during settlement, while also suggesting an increasing reliance on mineral-based turf resources for fuel at this site. In marked contrast to Hofstaðir, however, mineral based turf was also used for high temperature combustion throughout the period of midden formation, but especially prior to c. AD 950. Furthermore, there is no micromorphological evidence of peat utilisation, either for low temperature domestic use, or for high temperature, 'industrial', activity.

The Hofstaðir and Sveigakot, thin section samples have frequently occurring crystallitic groundmass $b$ fabrics and discrete very few, calcitic coarse mineral material; these features are also associated with charcoals that have distinct pore spaces (Tables 3 and 4; Figs. 7-9c). Together, these fabrics and features are interpreted as wood fuel ash residues. Wood fuel ash residues, both calcitic materials and charcoals, are found throughout the midden deposits, but are more common in later phases of accumulation, suggesting a greater intensity of wood use for fuel in the later part of the settlement period. Less frequent clustering of the crystallitic material in $\mathrm{b}$ fabrics suggests that some of the wood material used as fuel was combusted at high ('industrial') temperatures, and is also found throughout the stratigraphy, again becoming more frequent in upper horizons. At Sveigakot, there is substantial variation in the accumulation of wood fuel ash residues across the midden stratigraphy, with calcitic material absent and charcoals few in section $\mathrm{M} / \mathrm{wp}$, but with greater concentrations in sections M/sp and M/ws-ns. Such observations are more likely to represent variation in ash residue deposition rather than distinctions in fuel resource utilisation. Where present, crystallitic $b$ fabrics and charcoal colour are consistent with both birch and willow having been combusted at low temperatures, while the occurrence of clustered crystallitic $b$ fabrics suggest that there was also high temperature wood burning. There is no clear distinction between pre- and post c. AD 950 deposits, with no significant differences in the occurrence of wood ash residue micromorphology indicators. However, wood ash residue indicators are less frequent at Sveigakot in comparison with Hofstaðir.

Evidence for the use of animal manures as fuel sources is entirely lacking from the micromorphological evidence at Hofstaðir; it would appear that there were sufficient turf, peat and wood resources for fuel available to maintain settlement activity. In contrast, the occurrence of isotropic, black, fibrous and fragmented organic materials observed in thin section samples from Sveigakot post c. AD 950 suggests that cow manures were used as fuel sources here (Fig. 9d). Such an observation further re-enforces the view that Sveigakot was in a marginal environment, from which a wider range of fuel resources had to be exploited to maintain the settlement. There is no micromorphological evidence indicating the utilisation of sheep dung as a fuel source.

\section{Conclusions}

This research has established that there are distinctive micromorphological attributes in historically defined and experimentally combusted fuel materials that can be 
Table 4

Summary micromorphological descriptions of thin sections from Sveigakot, profiles M/ws-ns, M/wp and M/sp

\begin{tabular}{|c|c|c|c|c|c|c|c|c|c|c|c|c|c|c|c|}
\hline \multirow[t]{2}{*}{ Section } & \multirow[t]{2}{*}{ Micro-horizon } & \multicolumn{6}{|c|}{ Coarse mineral material } & \multicolumn{4}{|c|}{ Fine mineral material (oil) } & \multicolumn{3}{|c|}{ Organic material } & \multirow[t]{2}{*}{ Groundmass $b$ fabric } \\
\hline & & 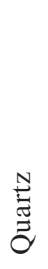 & $\frac{\frac{\pi}{0}}{\frac{0}{\pi}}$ & 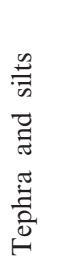 & $\begin{array}{l}\stackrel{\mathscr{\Xi}}{0} \\
\stackrel{\Xi}{0} \\
\stackrel{0}{0}\end{array}$ & 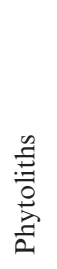 & 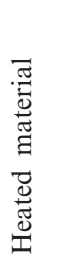 & $\stackrel{\overrightarrow{0}}{\simeq}$ & $\frac{3}{0}$ & 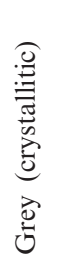 & 䓂 & 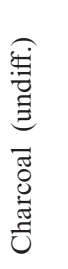 & $\begin{array}{l}\frac{a}{0} \\
\frac{0}{0} \\
0 \\
0 \\
0 \\
\frac{0}{2} \\
\frac{0}{0} \\
\vdots \\
\vdots\end{array}$ & 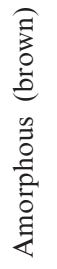 & \\
\hline \multirow[t]{4}{*}{ SVK/4 WS-NS } & 1 & $*$ & $*$ & $* * *$ & & & $* *$ & $*$ & $*$ & & & $* * *$ & $*$ & $*$ & Stipple and crystallitic \\
\hline & 2 & & & $* * *$ & & & & & & $*$ & $* * *$ & & & & Stipple \\
\hline & 3 & $*$ & $*$ & $* * *$ & & & $* *$ & $* *$ & & & & $* *$ & & & Stipple and crystallitic \\
\hline & 4 & $*$ & $*$ & $* * *$ & & & $* *$ & $* *$ & $*$ & $*$ & & $*$ & & & Stipple and crystallitic \\
\hline \multirow[t]{3}{*}{ SVK/3 WS-NS } & 1 & $*$ & $*$ & $* * *$ & & $*$ & $* * *$ & $* * *$ & $*$ & $*$ & & & & $*$ & Faint stipple \\
\hline & 2 & $*$ & $*$ & $* *$ & & * & $* *$ & $* *$ & $*$ & $*$ & ** & $* *$ & & $*$ & Stipple and crystallitic \\
\hline & 3 & $*$ & & $* * *$ & & & & $* * *$ & $*$ & & & $*$ & & $*$ & Stipple and crystallitic \\
\hline \multirow[t]{6}{*}{ SVK/2 WS-NS } & 1 & $*$ & $*$ & $* *$ & & & $* *$ & $*$ & $*$ & $*$ & & $*$ & & $*$ & Stipple and crystallitic \\
\hline & 2 & $*$ & $*$ & $* *$ & & & $* *$ & $*$ & $*$ & $*$ & $*$ & $* *$ & & $*$ & Stipple and crystallitic \\
\hline & 3 & & $*$ & $* *$ & & & $* *$ & $*$ & $*$ & $*$ & $*$ & $* *$ & & $*$ & Stipple and crystallitic \\
\hline & 4 & $*$ & $*$ & $* *$ & & & $* *$ & $*$ & $*$ & $*$ & $* *$ & $* *$ & $*$ & $*$ & Stipple and crystallitic \\
\hline & 5 & * & * & $* * *$ & & * & $* *$ & & & $*$ & ** & $* *$ & * & $*$ & Stipple and crystallitic \\
\hline & 6 & $*$ & & $* * *$ & & & & & & & & $*$ & & $*$ & Stipple \\
\hline \multirow[t]{7}{*}{ SVK/1 WS-NS } & 1 & $*$ & $*$ & $* *$ & & $*$ & & $* * *$ & & $*$ & & $* * *$ & & $*$ & Stipple and crystallitic \\
\hline & 2 & $*$ & & $* * *$ & & & & & & & & $*$ & & & Stipple \\
\hline & 3 & $*$ & $*$ & $* *$ & & & $* *$ & $* * *$ & & $*$ & & $* *$ & & $*$ & Stipple and crystallitic \\
\hline & 4 & $*$ & $*$ & $* * *$ & & & $*$ & & & $*$ & & $*$ & & $*$ & Stipple and crystallitic \\
\hline & 5 & $*$ & & $* * *$ & & & & & & & & & & & Stipple \\
\hline & 6 & $*$ & & $* * *$ & & & & & & & & & & & Stipple \\
\hline & 7 & $*$ & & $* * *$ & & & & & & & $* * *$ & & & & Stipple \\
\hline \multirow[t]{2}{*}{ SVK/SP1 } & 1 & & $*$ & $* *$ & & & $* *$ & $* *$ & $*$ & & & $*$ & $*$ & $*$ & $\begin{array}{l}\text { Faint stipple and } \\
\text { crystallitic }\end{array}$ \\
\hline & 2 & $*$ & & $* * *$ & & & & $*$ & & & & & * & & Faint stipple \\
\hline \multirow[t]{2}{*}{ SVK/SP2 } & 1 & & $*$ & $*$ & & & $* *$ & $*$ & & $* * * *$ & & $* *$ & & & Crystallitic \\
\hline & 2 & $*$ & & $* * *$ & & & & $*$ & & & & & $*$ & & Faint stipple \\
\hline \multirow[t]{3}{*}{ SVK/SP3 } & 1 & & & $* *$ & & & $* *$ & $* * *$ & & & & $*$ & & & Stipple \\
\hline & 2 & & $*$ & $*$ & & & $* *$ & $* * *$ & $*$ & $* * * *$ & & $*$ & & $*$ & Crystallitic \\
\hline & 3 & $*$ & & $* * *$ & & & & $*$ & & & & & $*$ & $*$ & Faint Stipple \\
\hline \multirow[t]{3}{*}{ SVK/SP4 } & 1 & & $*$ & $* *$ & & & $* *$ & $* * *$ & $*$ & & & $* *$ & & $*$ & Stipple and crystallitic \\
\hline & 2 & & $*$ & $*$ & & & $* *$ & $* *$ & $*$ & $* * * *$ & & $*$ & & $*$ & Crystallitic \\
\hline & 3 & $*$ & & $* * *$ & & & & & & & & & & $*$ & Faint stipple \\
\hline \multirow[t]{5}{*}{ SVK/SP5 } & 1 & $*$ & $*$ & $* * *$ & & & & $*$ & & & & & $*$ & $*$ & Stipple and crystallitic \\
\hline & 2 & & & $* *$ & & & & $* *$ & & & & $*$ & & & Stipple \\
\hline & 3 & $*$ & & $* * *$ & & & & $*$ & & & & $*$ & & $* *$ & Faint stipple \\
\hline & 4 & & $*$ & $*$ & & & $*$ & $*$ & & $* * * *$ & & $* * *$ & & & Crystallitic \\
\hline & 5 & $*$ & & $* * *$ & & & & $*$ & $*$ & & & & $*$ & $*$ & Faint stipple \\
\hline \multirow[t]{4}{*}{ SVK/WP6 } & 1 & & & $* *$ & & & $*$ & $* *$ & & & & $* *$ & & & Stipple \\
\hline & 2 & $*$ & & $* * *$ & & & & $*$ & & & & & $* *$ & & Faint stipple \\
\hline & 3 & & & $* *$ & & & $* *$ & $* *$ & & & & $* *$ & & & Stipple \\
\hline & 4 & $*$ & & $* * *$ & & & & $*$ & $*$ & & & & $*$ & $*$ & Faint stipple \\
\hline \multirow[t]{4}{*}{ SVK/WP7 } & 1 & & & $* *$ & & & & $*$ & & & & $* *$ & & & Stipple \\
\hline & 2 & $*$ & & $* * *$ & & & $* *$ & $*$ & & & & & $* *$ & & Faint stipple \\
\hline & 3 & & & $* *$ & & & $*$ & $* *$ & & & & $* *$ & & & Stipple \\
\hline & 4 & $*$ & & $* * *$ & & & & & & & & & & $*$ & Faint stipple \\
\hline
\end{tabular}


Table 4 (continued)

\begin{tabular}{|c|c|c|c|c|c|c|c|c|c|c|c|c|c|c|c|}
\hline \multirow[t]{2}{*}{ Section } & \multirow[t]{2}{*}{ Micro-horizon } & \multicolumn{6}{|c|}{ Coarse mineral material } & \multicolumn{4}{|c|}{ Fine mineral material (oil) } & \multicolumn{3}{|c|}{ Organic material } & \multirow[t]{2}{*}{ Groundmass $b$ fabric } \\
\hline & & 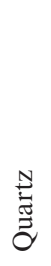 & 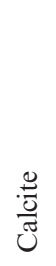 & 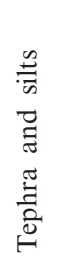 & 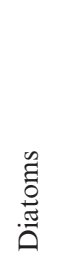 & 莺 & 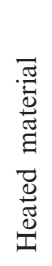 & $\stackrel{\vec{d}}{\simeq}$ & $\begin{array}{l}\frac{3}{0} \\
\frac{0}{2}\end{array}$ & 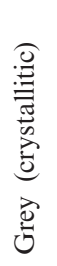 & 㫄 & 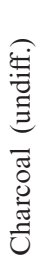 & 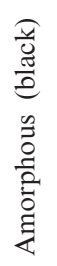 & 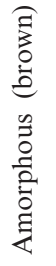 & \\
\hline SVK/WP8 & $\begin{array}{l}1 \\
2 \\
3\end{array}$ & * & & $\begin{array}{l}* * * \\
* * \\
* * *\end{array}$ & & & $*$ & $* *$ & & $*$ & & $* *$ & & * & $\begin{array}{l}\text { Faint stipple } \\
\text { Stipple } \\
\text { Faint stipple }\end{array}$ \\
\hline SVK/WP9 & $\begin{array}{l}1 \\
2\end{array}$ & * & & $\begin{array}{l}* * \\
* * *\end{array}$ & & & $*$ & $\begin{array}{l}* \\
*\end{array}$ & & & & $* *$ & $*$ & $*$ & $\begin{array}{l}\text { Stipple } \\
\text { Faint stipple }\end{array}$ \\
\hline SVK/WP10 & $\begin{array}{l}1 \\
2\end{array}$ & * & & $\begin{array}{l}* * \\
* * *\end{array}$ & & & $*$ & $* *$ & & $*$ & & $* *$ & & $*$ & $\begin{array}{l}\text { Stipple } \\
\text { Faint stipple }\end{array}$ \\
\hline
\end{tabular}

Frequency class refers to the area of section [8]. *Very few; **few; ***frequent/common; ****dominant/very dominant.

used to help interpret fuel residues found in settlement age archaeological site stratigraphies in Iceland. Furthermore, integration and complementary use of conventional thin section micromorphology and innovative image analyses methods has permitted a range of fuel ash residues to be identified and discriminated from other debris evident in midden deposits.

At the high status, and successful, Hofstaðir site fuel resources included peat, mineral-based turf and birch wood used throughout the period of midden formation, but with trends in utilisation mix. Residues from low temperature combustion of mineral-based turf are evident throughout the stratigraphy, although more concentrated during the earliest phases of midden formation. In contrast wood ash residues from low and high temperature combustion become more prevalent during later phases of midden formation. Peat utilisation is almost entirely associated with high temperature combustion and evident throughout the stratigraphy. At the more peripheral and ultimately abandoned Sveigakot site, fuel resources included mineral-based turf and wood materials, which were combusted at both high and low temperatures, together with cow dungs, which appear in later phases of the stratigraphy. Evidence of peat combustion is absent in samples from the Sveigakot midden stratigraphies. These observations suggest that the same range of domestic and 'industrial' activities requiring fuel were being attempted at both sites, although at a smaller scale at Sveigakot, but with a different mix of fuel resource materials.

We suggest that the first settlers in Iceland arrived fully understanding the fuel resource potential of landscapes and focussed on the extraction of wood, peat and turf material-although further work is required to define the origin of fuel resource selections in Norse society. Furthermore, we suggest that shortly after settlement, the mix of different fuel resources at high and low status landnám settlement sites was strongly influenced by cultural factors that can be inferred from fuel residue comparisons of the Hofstaðir and Sveigakot sites. Peat resources are clearly of importance in high temperature, 'industrial' activity at the high status Hofstaðir site, and it is possible to suggest that Hofstadir had access to these resources, while Sveigakot did not, even although ample peat resources are available some three kilometres from Sveigakot. Regulation of resources to maintain social hierarchy is a common social phenomenon in Iron Age society and research presented in this paper opens the issue of whether a social elite was regulating peat availability in the north of Iceland as a means of retaining and enhancing power and authority. Not only was the emerging legal framework and religious observances being used to enhance chieftain power [16], land resources - of which fuel resources were a part - may also have been used in this manner. Further evidence for fuel resource regulation is hinted at in the Hofstadir stratigraphy where increases in the proportion of wood utilisation suggests that woodland management may have promoted different age structures and densities of woodland, raising productivity for a time. Such a possibility is in contrast to the prevailing view of an Icelandic settlement period characterised by major woodland loss and land degradation, and may emphasise the significant role that large scale land management may have played in the successful maintenance of high status settlement age sites. In contrast, fuel resource regulation may have resulted in the occupants of Sveigakot resorting to more marginal fuel resources including willow wood and cow dungs. Reinforced by an increasingly deteriorating 


\section{G108}
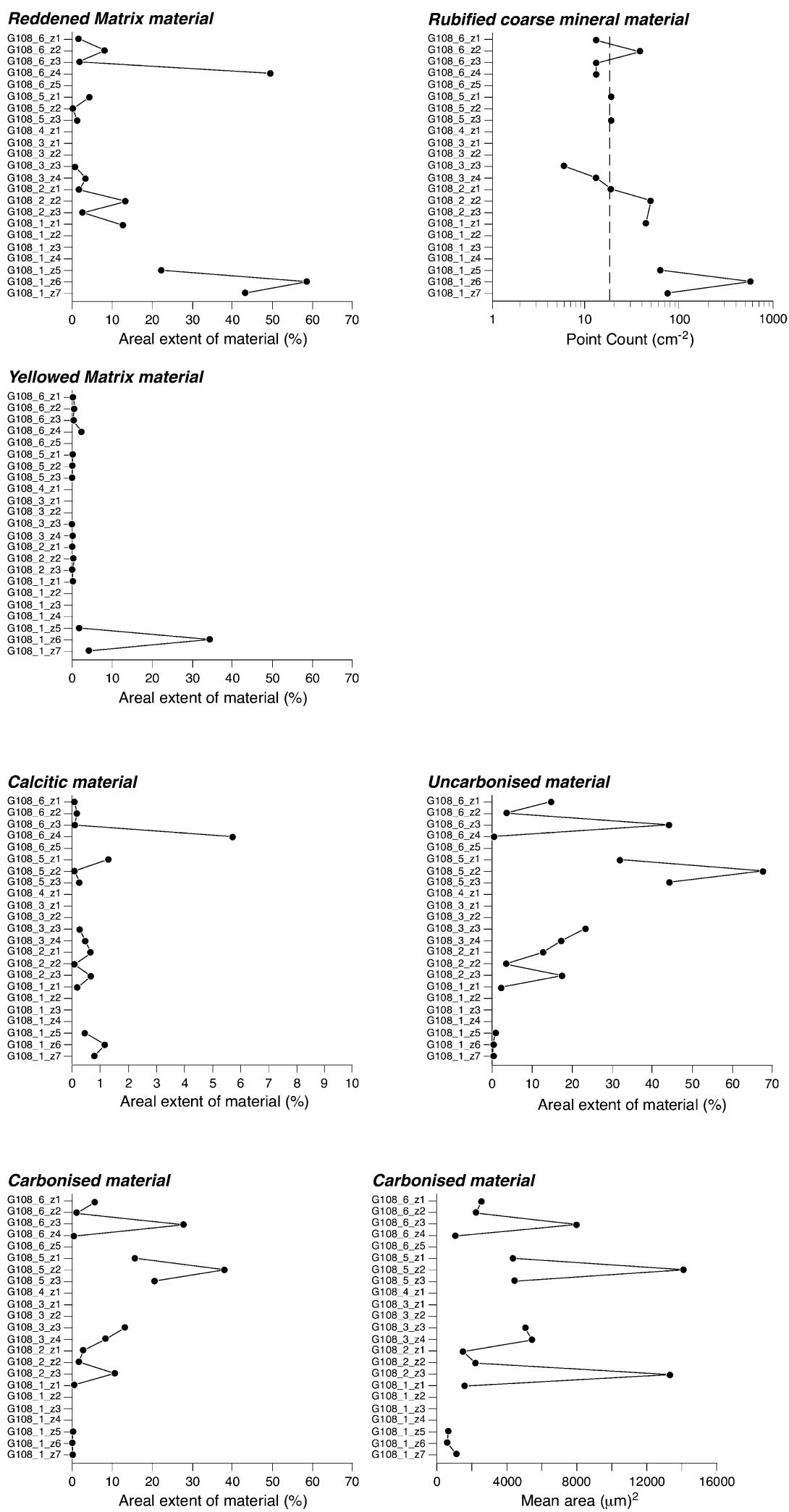

Fig. 7. Image analysis measurements of sections from Hofstaðir, section G108. 


\section{G109}
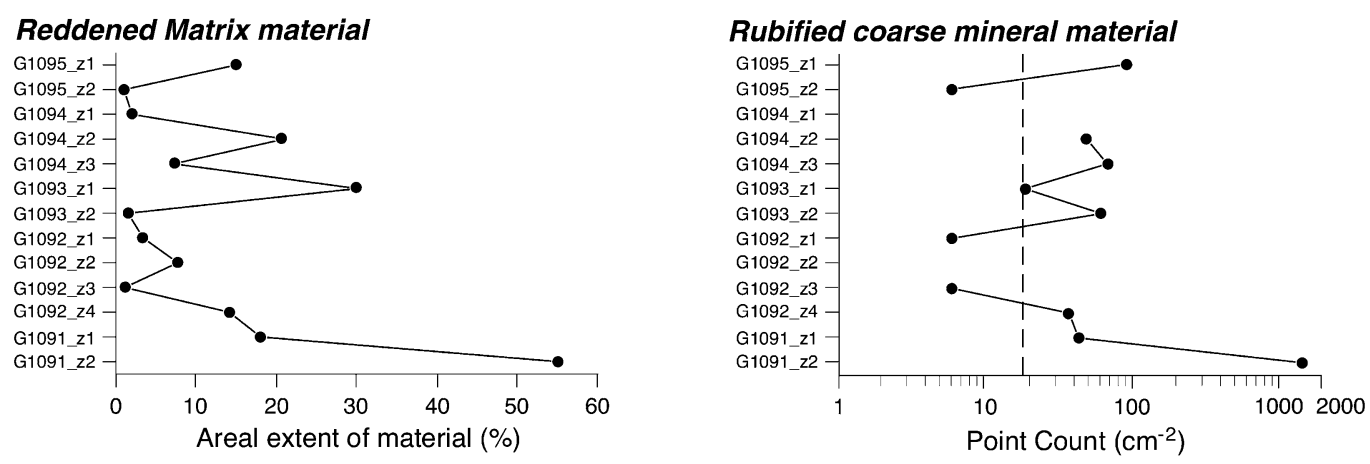

Yellowed Matrix material
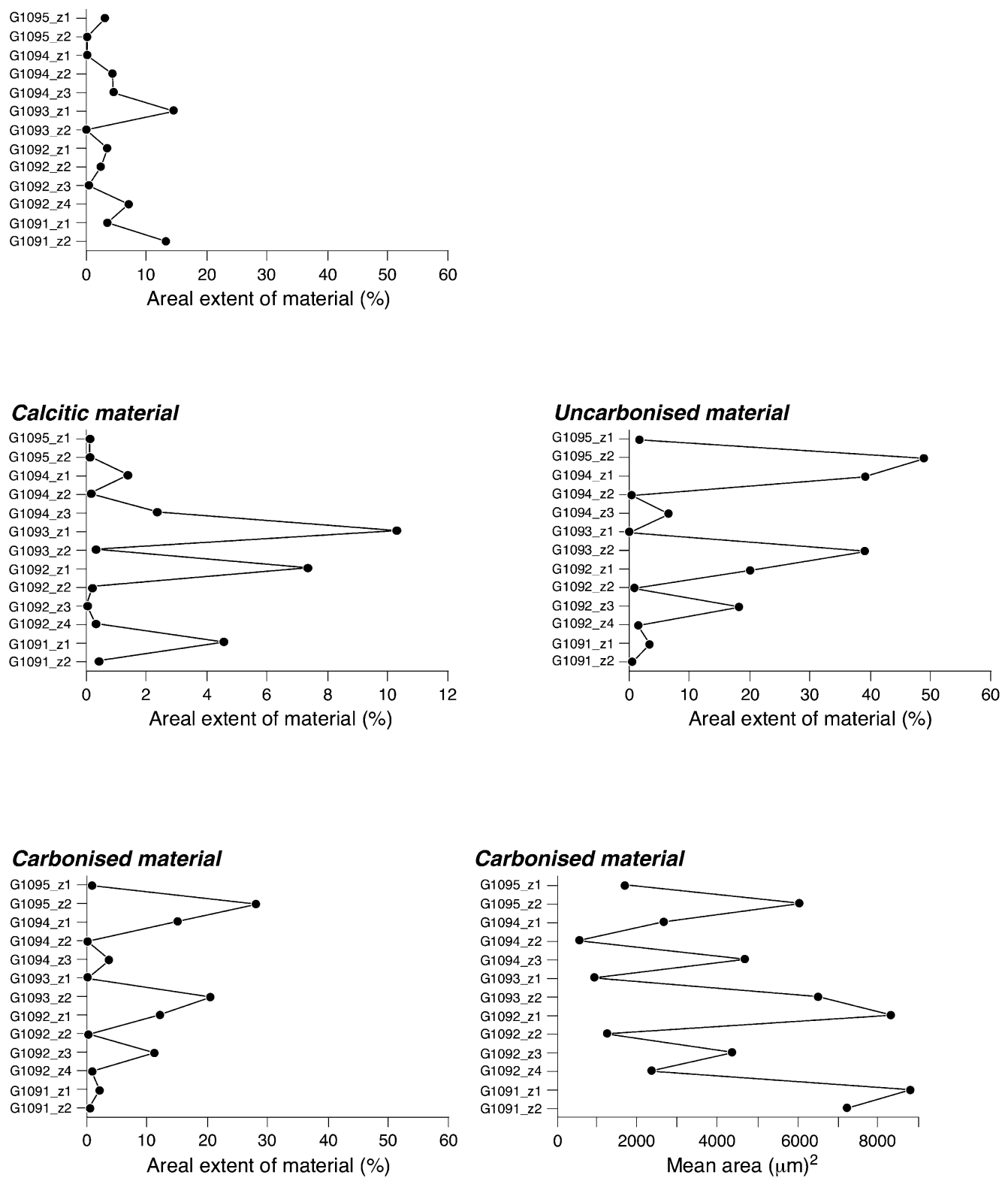

Fig. 8. Image analysis measurements of sections from Hofstaðir, section G109. 
Table 5

Results of image analysis of thin-section materials from Sveigakot

\begin{tabular}{|c|c|c|c|c|c|c|c|c|}
\hline Sample & $\begin{array}{l}\text { Reddened matrix } \\
\text { material } \%\end{array}$ & $\begin{array}{l}\text { Rubified coarse mineral } \\
\text { material } \%\end{array}$ & $\begin{array}{l}\text { Count-rubified coarse } \\
\text { mineral material } \mathrm{cm}^{-2}\end{array}$ & $\begin{array}{l}\text { Yellowed matrix } \\
\text { material } \%\end{array}$ & $\begin{array}{l}\text { Uncarbonised } \\
\text { material } \%\end{array}$ & $\begin{array}{l}\text { Calcitic } \\
\text { material \% }\end{array}$ & $\begin{array}{l}\text { Carbonised } \\
\text { material } \%\end{array}$ & $\begin{array}{l}\text { Mean area of carbonised } \\
\text { material } \mu \mathrm{m}^{2}\end{array}$ \\
\hline SVK_4_z1 & 2.1 & 0.02 & 56 & nd & nd & 1.4 & 30.0 & 9017 \\
\hline SVK_4_z3 & 4.1 & nd & 0 & 0.01 & nd & 0.0 & 12.8 & 5742 \\
\hline SVK_4_z4 & 6.6 & 0.03 & 75 & nd & nd & 0.91 & 4.7 & 1514 \\
\hline SVK_3_zl & 43.7 & 0.71 & 1500 & 0.02 & nd & 0.6 & 0.5 & 1147 \\
\hline SVK_3_z2 & 10.2 & 0.02 & 38 & 0.01 & nd & 0.0 & 9.4 & 4480 \\
\hline SVK_3_z3 & 37.4 & 0.26 & 419 & nd & 0.19 & 0.8 & 0.0 & 746 \\
\hline SVK_2_zl & 0.8 & 0.11 & 181 & nd & 0.10 & 0.1 & 3.1 & 684 \\
\hline SVK_2_z3 & 0.6 & 0.03 & 50 & nd & 0.03 & 0.6 & 9.1 & 1655 \\
\hline SVK_2_z4 & 2.6 & 0.11 & 175 & 0.02 & 0.02 & 0.3 & 11.7 & 1213 \\
\hline SVK_2_z5 & 0.8 & 0.02 & 56 & nd & nd & 0.0 & 4.9 & 1056 \\
\hline SVK_2_z6 & 0.8 & 0.13 & 150 & nd & nd & 0.1 & 3.5 & 564 \\
\hline SVK_SP_1_z1 & 5.6 & 0.25 & 531 & 0.01 & 0.01 & 0.01 & 4.4 & 1425 \\
\hline SVK_SP_1_z2 & 0.7 & 0.11 & 88 & nd & nd & 0.01 & 5.9 & 1316 \\
\hline SVK_SP_2_z1 & 0.5 & 0.05 & 88 & nd & nd & 0.02 & 11.9 & 1687 \\
\hline SVK_SP_2_z2 & 0.2 & 0.05 & 38 & nd & nd & 0.01 & 7.7 & 1070 \\
\hline SVK_SP_3_z2 & 12.0 & 1.38 & 1763 & 0.05 & 0.05 & 0.04 & 3.0 & 973 \\
\hline SVK_SP_3_z3 & 0.7 & 0.05 & 81 & nd & nd & 0.01 & 4.0 & 854 \\
\hline SVK_SP_4_z1 & 20.3 & 0.03 & 63 & 0.02 & 0.02 & 0.70 & 5.2 & 1216 \\
\hline SVK_SP_4_z2 & 7.1 & 0.09 & 156 & 0.08 & 0.08 & 0.12 & 0.5 & 941 \\
\hline SVK_SP_5_z1 & 0.2 & 0.01 & 6 & nd & 4.30 & 0.01 & 6.2 & 1060 \\
\hline SVK_SP_5_z3 & 0.1 & nd & nd & nd & 14.03 & 0.01 & 5.4 & 1197 \\
\hline SVK_SP_5_z4 & 0.9 & nd & 6 & nd & nd & 0.05 & 19.4 & 3663 \\
\hline SVK_SP_5_z5 & 0.1 & nd & nd & 0.01 & 0.01 & 0.04 & nd & 827 \\
\hline SVK_WP_6_z2 & 0.1 & nd & 6 & nd & nd & nd & 8.8 & 882 \\
\hline SVK_WP_6_z4 & 3.3 & 0.42 & 675 & 0.01 & 0.0 & 0.01 & 1.4 & 806 \\
\hline SVK_WP_7_z1 & 0.4 & 0.05 & 81 & nd & nd & nd & 15.5 & 962 \\
\hline SVK_WP_7_z2 & 2.1 & 0.17 & 225 & nd & nd & nd & 10.8 & 1843 \\
\hline SVK_WP_9_z1 & 0.1 & nd & 6 & nd & nd & nd & 21.9 & 2767 \\
\hline SVK_WP_9_z2 & 1.2 & 0.04 & 50 & nd & 0.0 & 0.0 & 3.7 & 1053 \\
\hline
\end{tabular}

nd: No object detected. 

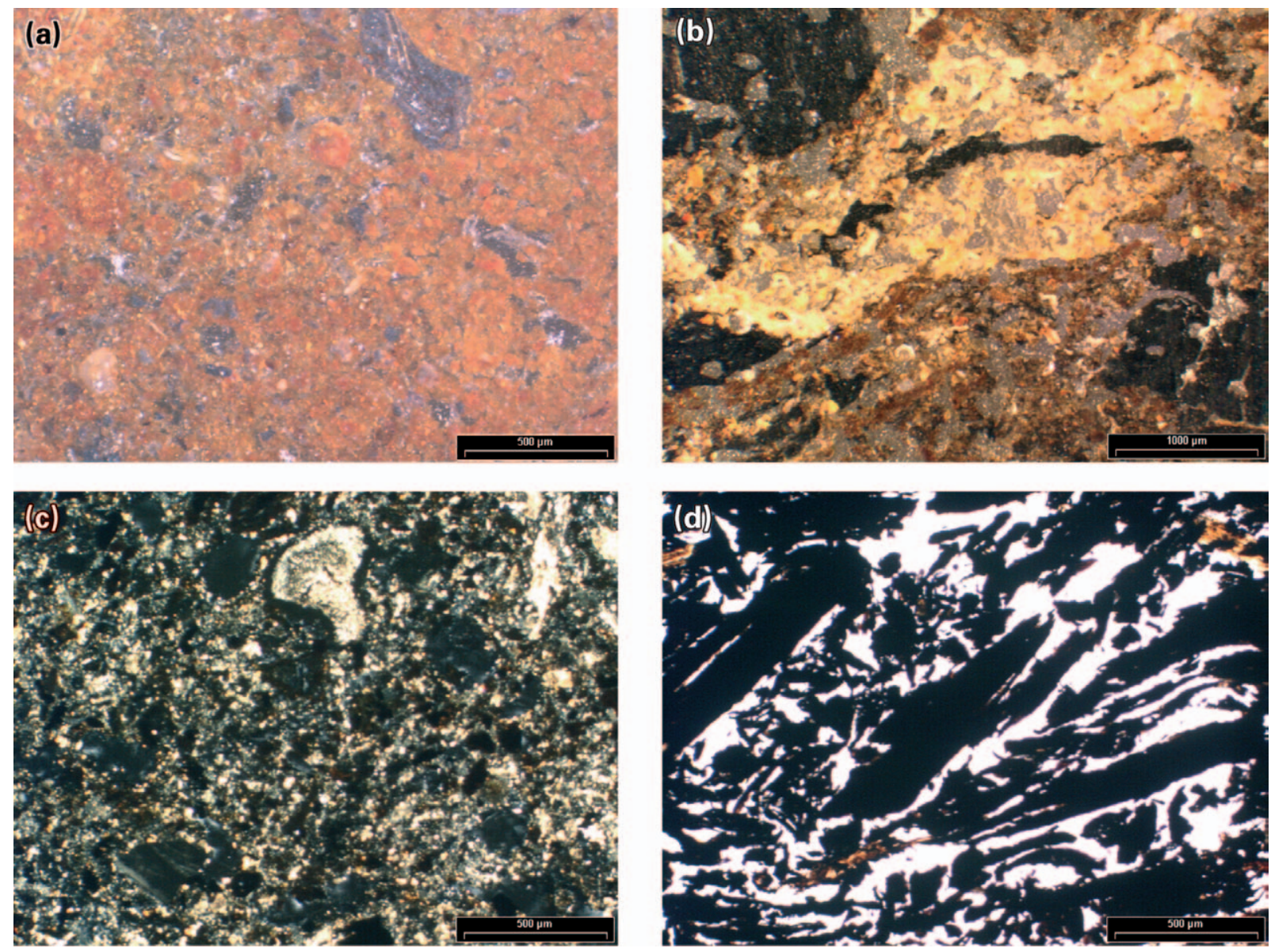

Fig. 9. Micromorphological features indicative of fuel ash residues in midden deposits from northern Iceland: (a) Rubified fine mineral material with rubified coarse mineral material under oblique incident light, Hofstaðir section G108, thin section sample 1; interpreted as residues of mineral-based turf material combusted at low temperature. (b) Yellow fine mineral material under oblique incident light, Hofstaðir section G108, thin section sample 5; interpreted as residues of peat combusted high temperatures. (c) Crystallitic b fabric under crossed polars, Hofstaðir section 109, thin section sample 3; interpreted as ash residues from wood combustion. (d) Black fragmented organic material under plane polarised light, Sveigakot section $\mathrm{M} / \mathrm{ws}-\mathrm{ns}$, thin section sample 2; interpreted as residues of cow dung combusted at low temperatures.

local environment driven by overgrazing and land exploitation [32], and evidenced as aeolian accumulation within the midden stratigraphy, this may have been sufficient to result in the early abandonment of the Sveigakot site. This further emphasises a key role for fuel resource availability in the success or failure of early settlement sites and highlights the spatial complexity of fuel resource utilisation in landscapes of settlement.

\section{Acknowledgements}

Ian Simpson gratefully acknowledges support from the Carnegie Trust for the Universities of Scotland, the Leverhulme Trust and the US National Science Foundation. Orri Vésteinsson gratefully acknowledges the support of the Icelandic Research Council and the Mývatn Research Station. Paul Adderley kindly acknowledges the support of the Leverhulme Trust. Tom McGovern gratefully acknowledges generous support from the US National Science Foundation
(Archaeology and Arctic Social Sciences programs), the Committee for Research and Exploration of the National Geographic Society, and the PSC-CUNY grants program. George Macleod manufactured the thin sections at the University of Stirling. Tables and figures were produced by Bill Jamieson at the University of Stirling. Matt Canti of English Heritage offered invaluable advice during the early stages of this project.

\section{References}

[1] W.P. Adderley, I.A. Simpson, D.A. Davidson, Colour description and quantification in mosaic images of soil thin sections, Geoderma 108 (2002) 181-195.

[2] T. Amorosi, P.C. Buckland, K.J. Edwards, I.L. Mainland, T.H. McGovern, J.P. Sadler, P. Skidmore, They did not live by grass alone: the politics and palaeoecology of animal fodder in the North Atlantic region, Environmental Archaeology 1 (1998) $55-62$.

[3] W. Balee (Ed.), Advances in Historical Ecology, Columbia University Press, New York, 1998 
[4] J. Benediktsson, Some problems in the history of the settlement of Iceland, in: T. Andersson, K.I. Sandred (Eds.), The Vikings, Almmqvist and Wiksell International, Stockholm, 1978, pp. 161-165.

[5] J.E. Brochier, Les Sediments Anthrophiques. Méthodes d'études et perspectives, in: J.C. Miskovsky (Ed.), Géologie de la Préhistorie: méthodes, techniques, applications, Géopré Editions, Paris, 2002, pp. 453-477.

[6] J.E. Brochier, P. Villa, M. Giacomarra, A. Tagliacozzo, Shepherds and sediments: geo-ethnoarchaeology of pastoral sites, Journal of Anthropological Archaeology 11 (1992) 47-102.

[7] J.E. Brochier, M. Thinon, Comment on calcite crystals inside archaeological plant tissues, Journal of Archaeological Science (in press).

[8] P. Bullock, N. Federoff, A. Jongerius, Stoops, T. Tursina, U. Babel, Handbook for Soil Thin Section Description, Waine Research Publications, Wolverhampton, 1985.

[9] M.G. Canti, Aspects of the chemical and microscopic characteristics of plant ashes found in archaeological soils, Catena (in press).

[10] M.A. Courty, P. Goldberg, R.I. Maphail, Soils and Micromorphology in Archaeology, Cambridge University Press, Cambridge, 1989.

[11] C.L. Crumley, Historical Ecology: Cultural Knowledge and Changing Landscapes, School of American Research Press, Santa Fe, 1994.

[12] E. February, Archaeological charcoals as indicators of vegetation change and human fuel choice in the late Holocene at Elands Bay, South Africa, Journal of Archaeological Science 19 (1991) 347-354.

[13] E.A. Fitzpatrick, Micromorphology of Soils, Chapman \& Hall, London, 1984

[14] A. Friðriksson, O. Vésteinsson, Hofstaðir revisited, Norwegian Archaeological Review 30 (1997) 103-112.

[15] A. Friðriksson, O. Vésteinsson, Creating a past. A Histiography of the settlement of Iceland, in: J. Barrett (Ed.), Contact, Continuity and Collapse: The Norse Colonization of the North Atlantic. Brepols, York Studies in the Early Middle Ages, Turnhout (in press)

[16] A. Friðriksson, O. Vésteinsson, T. McGovern, Recent investigations at Hofstaðir, Northern Iceland. Proceedings of the NABO/ AEA Conference. Glasgow March/April 2001 (in press).

[17] K. Grönvold, N. Óskarsson, S.J. Johnsen, H.B. Clausen, C.U. Hammer, G. Bond, E. Bard, Ash layers from Iceland in the Greenland GRIP ice core correlated with oceanic and land sediments, Earth and Planetary Science Letters 135 (1995) 149-155.

[18] M. Hallsdóttir, Pollen analytical studies of human influence on vegetation in relation to the landnám tephra layer in southwest Iceland, Lundqua Thesis 18, Department of Quaternary Geology, Lund University, 1987.

[19] B. Jóhannesson, The Soils of Iceland, Department of Agriculture Reports Series b no. 13, University Research Institute, Reykjavík, 1960.

[20] P.V. Kirsch, T. Hunt, Historical Ecology in the Pacific Islands: Prehistoric Environmental and Landscape Change, Yale University Press, Santa Fe, 1997.

[21] G. Lucas (Ed.), Hofstaðir 1999. Preliminary Reports, Fornleifastofnun Íslands, Reykjavík, 1999.

[22] T.H. McGovern, G.F. Bigelow, T. Amorosi, D. Russell, Northern islands, human error and environmental degradation: a preliminary model for social and ecological change in the medieval north Atlantic, Human Ecology 16 (1988) 45-105.
[23] T. McGovern, Area G excavation report, in: A. Friðriksson, O. Vésteinsson (Eds.), Hofstaðir 1998: Preliminary reports, Fornleifastofnun Íslands, Reykjavík, 1998.

[24] B. Melsteð, F. Jónsson, B. pórlófsson (Eds), Jarðabók Árna Magnússonar og Páls Vídalín 1-11, Copenhagen, 1913-1943; 12-13, Reykjavík, 1990, 1913-90.

[25] C.P. Murphy, Thin Section Preparation of Soils and Sediments, AB Academic Publishers, Berkhampstead, 1986.

[26] C. Pierce, K.R. Adams, J.D. Stewart, Determining the fuel constituents of ancient hearth ash via ICP-AES analyses, Journal of Archaeological Science 25 (1998) 493-503.

[27] J. Prior, D.P. Williams, An investigation of climatic change in the Holocene epoch using archaeological charcoal from Swaziland, South Africa, Journal of Archaeological Science 12 (1985) 457-475.

[28] S. Scheigl, P. Goldberg, O. Bar-Yosef, S. Weiner, Ash deposits in Hayonim and Kebara caves, Israel: macroscopic, microscopic and mineralogical observations, and their archaeological implications, Journal of Archaeological Science 23 (1996) 763-781.

[29] Ḿ. Sigurgeirsson, O. Vésteinsson, H. Halfliðason, Gjóskulagarannsóknir við Mývatn-aldursgreining elstu byggðar, in: O. Vésteinsson (Ed.), Archaeological investigations at Sveigakot. 2001, with reports on preliminary investigations at Hrísheimar, Selhagi and Ytri Tunga, Fornleifastofnun Íslands, Reykjavík, 2002, pp. 108-110.

[30] I.A. Simpson, K.B. Milek, G. Guðmundsson, A re-interpretation of the great pit at Hofstaðir Iceland, using sediment thin section micromorphology, Geoarchaology 14 (1999) 511-530.

[31] I.A. Simpson, A.J. Dugmore, A. Thomson, O. Vésteinsson, Crossing the thresholds: Human ecology and historical patterns of landscape degradation, Catena 42 (2001) 175-192.

[32] I.A. Simpson, G. Guðmundsson, A.M. Thomson, J. Cleutt, Assessing the role of winter grazing in historical land degradation, Mývatnssveit, north-east Iceland, Geoarchaeology (in press).

[33] K.P. Smith, Landnám: the settlement of Iceland in archaeological and historical perspective, World Archaeology 26 (1995) 319-347.

[34] Soil Survey Staff, Keys to Soil Taxonomy, 8th edn, U.S. Department of Agriculture, Natural Resources Conservation Service, Washington, DC, 1998.

[35] M. Stuiver, J. van der Plicht, Editorial comment, Radiocarbon 40 (1998) xii-xiv.

[36] M. Stuiver, P.J. Reimer, E. Bard, J.W. Beck, G.S. Burr, K.A. Hughen, B. Kromer, G. McCormac, J. van der Plicht, M. Spurk, INTCAL98 radiocarbon age calibration 24,000-0 cal BP, Radiocarbon 40 (1998) 1041-1083.

[37] A.S. Talma, J.C. Vogel, A simplified approach to calibrating C14 dates, Radiocarbon 35 (1993) 317-322.

[38] C.E. Umbanhower, M. McGrath, Experimental production and analysis of microscopic charcoal from wood, leaves and grasses, The Holocene 8 (1998) 341-346.

[39] O. Vésteinsson, Area G, in: G. Lucas (Ed.), Hofstaðir 1999. Preliminary Reports, Fornleifastofnun Íslands, Reykjavík, 1999.

[40] O. Vésteinsson (Ed.), Archaeological investigations at Sveigakot 1998-2000, Fornleifastofnun Íslands, Reykjavík, 2001.

[41] O. Vésteinsson, Patterns of settlement in Iceland: a study in prehistory, Saga-Book 28 (1998) 1-29.

[42] O. Vésteinsson, The archaeology of landnám: early settlement in Iceland, in: W.W. Fitzhugh, E.I. Ward (Eds.), Vikings: the North Atlantic Saga, Smithsonian Institution Press, Washington, 2000, pp. 164-174.

[43] O. Vésteinsson, T.H. McGovern, C. Keller, Enduring impacts: social and environmental aspects of Viking Age settlement in Iceland and Greenland, Archaeologia Islandica 2 (2002) 98-136. 